\title{
Energy Efficiency Measures in Affordable Zero Net Energy Housing: A Case Study of the UC Davis 2015 Solar Decathlon Home
}

\author{
Payman Alemi ${ }^{\mathrm{a}}$, Frank Loge $\mathrm{a}^{\mathrm{a}}$ \\ ${ }^{a}$ Department of Civil and Environmental Engineering, University of California, Davis, CA 95616, USA
}

\begin{abstract}
The 2015 UC Davis Solar Decathlon Team designed and constructed an affordable zero net energy prototype home for California (CA) farmworkers. The prototype was modeled with BEopt and Microsoft Excel ${ }^{\circledR}$ for year-round operation under the Davis, CA climate. Each major energy-efficient feature of the home was separately analyzed to gauge its energy savings impact. The construction strategy of in-line framing, low window to wall ratio, and thermal mass in the floor, annually saved $810 \mathrm{kWh}$ in space conditioning. The appliance scoring methodology evaluated appliances based on water efficiency, energy efficiency, and affordability - this methodology led to the adoption of appliances that yielded an annual energy savings exceeding $400 \mathrm{kWh}$. A graywater heat recovery system selected for the project, the Nexus, saved roughly $3500 \mathrm{kWh}$ annually of electricity compared to an electric resistance water heater. The combined radiant/night sky system reduced the space conditioning energy of the home by nearly $1,400 \mathrm{kWh}$. Over a full year, the UC Davis Solar Decathlon home is anticipated to be $12.9 \%$ net energy positive and consume $43.8 \%$ less energy than a conventional home, with the same floor plan, exposed to the Davis climate.
\end{abstract}

Keywords: Residential Housing; Energy Modeling; Zero Net Energy; Energy Efficiency

\section{Introduction}

For its entry in the U.S. Department of Energy (DOE) Solar Decathlon Competition 2015, the UC Davis Solar Decathlon Team, "Team Aggie Sol," designed a $1009 \mathrm{ft}^{2}\left(91.9 \mathrm{~m}^{2}\right)$ house as a prototype home for farmworkers in California (CA). The team's primary objective was to build an affordable Zero Net Energy (ZNE) house that otherwise performed well in the other contest areas. The 10 contest areas, each worth 100 points, included [1]:

1. Architecture: Design evaluated on the architectural concept, implementation, innovation, and documentation, by a jury of architects.

2. Market Appeal: Design evaluated on how effectively it addressed the needs of its target audience, by a jury of homebuilding industry professionals.

3. Engineering: Design evaluated on the innovation, functionality, efficiency, reliability and documentation of its engineered systems, by a jury of engineers.

4. Communications Contest: Team evaluated on the seamlessness and effectiveness of its communications materials

5. Comfort Zone: Points awarded based on the house's adherence to the required temperature range of $71.0^{\circ} \mathrm{F}\left(21.7^{\circ} \mathrm{C}\right)$ to $76.0^{\circ} \mathrm{F}\left(24.4^{\circ} \mathrm{C}\right)$ and maximum relative humidity threshold of $60.0 \%$.

6. Appliances: Points awarded based on the functionality of the home appliances.

7. Home Life: Points awarded based on the functionality of the home's lighting, hot water production, electronics, and successfully hosting two dinner parties.

8. Commuting: Points awarded based on driving an electric vehicle, charged by the house, 200 miles in eight separate trips.

9. Energy Balance: Full points awarded for the house being zero or positive net energy and consuming $175 \mathrm{kWh}$ or less during the competition week (October 8 to October 16, 2015).

10. Affordability: Full points awarded to teams with estimated construction costs less than $\$ 250,000$.

Thirteen other teams competed in the U.S. DOE Solar Decathlon 2015; Team Aggie Sol finished first in the Affordability Contest (estimated construction costs were \$249,312) and seventh overall. Stevens Institute of Technology was the overall winner of the competition. Additional details of the competition can be found at http://www.solardecathlon.gov. The overall objective of this paper is to document the design process that lead to an affordable ZNE house. The Aggie Sol home was designed with a multi-faceted approach to energy efficiency that targeted the following five areas:

*Corresponding author. Tel.: (530) 754-2297. Email Address: fjloge@ ucdavis.edu (F. Loge) 


\begin{tabular}{|c|c|c|c|}
\hline \multicolumn{2}{|l|}{ Nomenclature } & \multicolumn{2}{|c|}{ Subscripts and superscripts } \\
\hline 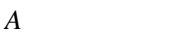 & area, $\mathrm{ft}^{2}$ & a & ambient air \\
\hline $\mathrm{ACH}$ & air changes per hour & A & availability \\
\hline$A D A$ & American Disabilities Act & $\mathrm{C}$ & cost \\
\hline$B$ & equation of time factor & Compressor & compressor of SPX 50 DHPT water heater \\
\hline$C F L$ & compact fluorescent light bulb & conv & convection \\
\hline$C F M$ & cubic feet per minute & CWST & chilled water storage tank \\
\hline$E$ & electricity production, $\mathrm{kWh}$ & $\mathrm{dp}$ & dewpoint \\
\hline$E F$ & energy factor & $\mathrm{E}$ & energy efficiency \\
\hline EoT & equation of time, minutes & evap & evaporation \\
\hline$G_{b}$ & beam radiation on a horizontal surface, $\mathrm{W} / \mathrm{m}^{2}$ & HPWH & heat pump water heater \\
\hline$G_{b t}$ & beam radiation on a tilted surface, $\mathrm{W} / \mathrm{m}^{2}$ & $\mathrm{i}$ & refers to any given item in a collection \\
\hline$G P M$ & gallons per minute & $\mathrm{L}$ & aesthetics \\
\hline$G_{T}$ & total beam radiation received by a photovoltaic panel, $\mathrm{W} / \mathrm{m}^{2}$ & $\max$ & maximum \\
\hline$H D P E$ & high density polyethylene & $\min$ & minimum \\
\hline$H S P F$ & heating season performance factor & $\mathrm{mp}$ & maximum power point of a photovoltaic panel \\
\hline HVAC & heating, ventilation, and air conditioning & NOCT & normal operating cell temperature \\
\hline$L E D$ & light emitting diode & $\mathrm{O}$ & operative \\
\hline Lloc & local meridian, ${ }^{\circ}$ & Panel & individual photovoltaic panel \\
\hline$L_{s t}$ & standard meridian, $^{\circ}$ & Pond & water sprayed onto Aggie Sol roof \\
\hline$M S R P$ & manufacturer suggested retail price & $\mathrm{rad}$ & radiation \\
\hline$n$ & day of the year & Ref & panel properties at reference temperature \\
\hline PEX & cross-linked polyethylene & Roof & Aggie Sol roof \\
\hline$O S B$ & oriented strand board & SHGC & solar heat gain coefficient \\
\hline PSI & pressure per square inch & Sky & night sky \\
\hline $\mathrm{OH}$ & operating hours & W & water efficiency \\
\hline$Q$ & heat, BTU & & \\
\hline$S$ & wind speed, $\mathrm{m} / \mathrm{s}$ & & \\
\hline SEER & seasonal energy efficiency ratio & & \\
\hline Standard Time & 24 hour clock time, $\min$ & & \\
\hline Solar Time & time based on apparent angular motion of the sun, min & & \\
\hline$T$ & temperature, ${ }^{\circ} \mathrm{F}$ & & \\
\hline$T P O$ & thermoplastic olefin & & \\
\hline$T_{r}$ & mean radiant temperature, ${ }^{\circ} \mathrm{F}$ & & \\
\hline$V$ & wind speed, $\mathrm{m} / \mathrm{s}$ & & \\
\hline$W$ & weighting factor & & \\
\hline$T_{c}$ & temperature of photovoltaic cell, ${ }^{\circ} \mathrm{C}$ & & \\
\hline$w$ & hour angle, ${ }^{\circ}$ & & \\
\hline$X$ & score from 0 to 10 assigned to an appliance category & & \\
\hline ZNE & zero net energy & & \\
\hline \multicolumn{4}{|l|}{ Greek symbols } \\
\hline$\beta$ & slope, ${ }^{\circ}$ & & \\
\hline$\gamma$ & surface azimuth angle, ${ }^{\circ}$ & & \\
\hline$\gamma_{s}$ & solar azimuth angle, ${ }^{\circ}$ & & \\
\hline$\delta$ & declination angle, ${ }^{\circ}$ & & \\
\hline$\eta$ & efficiency & & \\
\hline$\theta_{z}$ & zenith angle, $^{\circ}$ & & \\
\hline $\begin{array}{l}\mu_{n, m p} \\
\sigma\end{array}$ & $\begin{array}{l}\text { maximum power point efficiency temperature coefficient, } \\
\text { Stefan-Boltzmann constant, }\end{array}$ & & \\
\hline$\varphi$ & latitude, ${ }^{\circ}$ & & \\
\hline
\end{tabular}

\subsection{Construction Materials:}

By utilizing an in-line framing method, the home required substantially less lumber, thereby reducing cost, but also allowing more room for insulation, thereby reducing heating and cooling loads. By reducing the window to wall ratio, the home also eliminated significant heat loss during the winter and heat gain during the summer. The last major construction choice was gypsum concrete as thermal mass in the floor to cover the radiant loops.

\subsection{Appliance Selection:}

Team Aggie Sol carefully selected home appliances by using an appliance scoring methodology that evaluated water efficiency, energy efficiency, aesthetics, cost, and availability. Increased energy efficiency results in less electricity consumed and smaller internal gains, while improved water efficiency translates into hot water energy savings. 


\subsection{Radiant Heating and Cooling System and Night Sky Cooling System}

The heating system was made more efficient by replacing a traditional forced air heating, ventilation, and air conditioning (HVAC) system with an under-floor radiant heating and cooling system. The radiant system almost completely eliminates duct losses, replaces an air handler with a low-energy circulating water pump, and expands the range of comfortable indoor air temperature. The source of the hot water running in the radiant pumps was a State SPX 50 DHPT heat pump water heater (State HPWH) [2]. The source of the cold water running in the radiant pipes was the night sky cooling system. The night sky cooling system consisted of a 1500 gallon chilled water storage tank (CWST), another low energy water circulator, and rooftop sprinklers ("night sky sprinklers"). The sprinklers spray water on the roof surface at night, where it loses heat to the sky via radiation. This cooling system is very energy efficient compared to a reversible heat pump, the traditional method of producing cold water for radiant cooling. For the competition, the night sky cooling system was pre-filled with potable water, while during year-round operation, the system will run on rainwater collected by the butterfly roof.

\subsection{Graywater Heat Recovery}

A standard electric resistance water heater generally has an energy factor (EF) of 1.0 or less-EF measures the fraction of water heater input energy remaining in 64 gallons $(242 \mathrm{~L})$ of hot water extracted from the water heater [3]. Instead of using such a water heater, the Aggie Sol home used the Nexus graywater heat recovery system that features an EF of 4.0. The system consists of a collection tank (NEXcollector) that captures heat from incoming graywater and transfers it to the 80 gallon NEXheater via refrigerant [4]. The Aggie Sol home is dual-plumbed to separate graywater (water from the vanity sinks, clothes washer, and showers [5]) and blackwater (water from the kitchen sink and toilets) —only graywater enters the NEXcollector [6]. The NEXheater is an electric heat pump that heats incoming cold water to generate the home's domestic hot water [7].

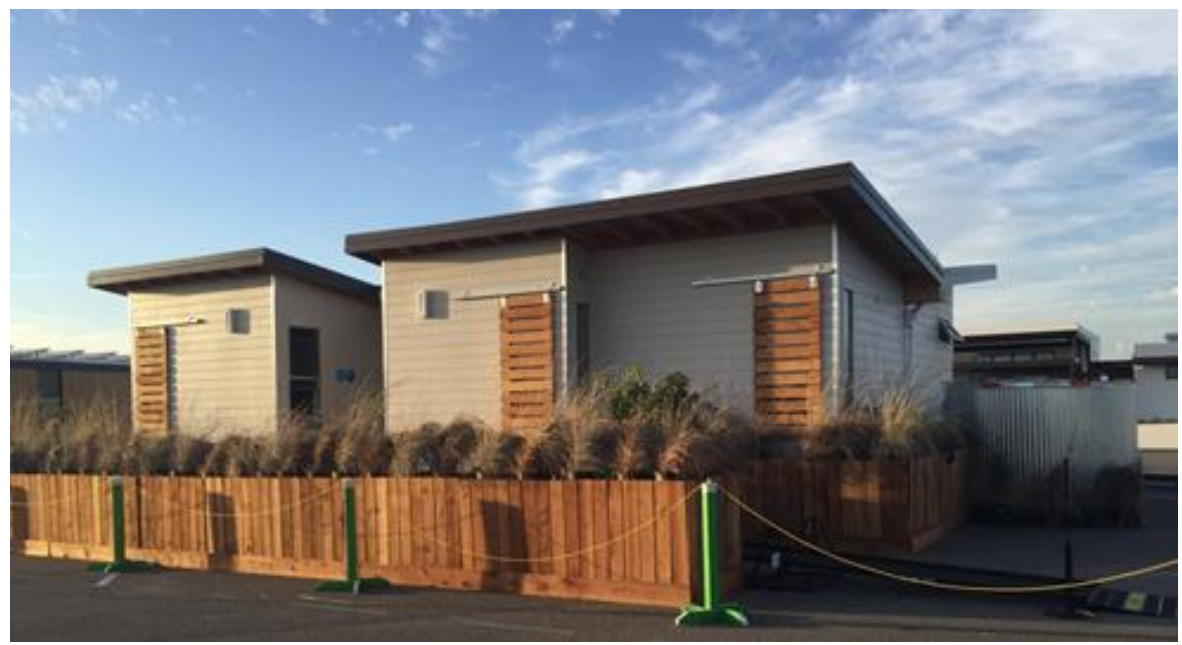

Fig. 1. Aggie Sol as erected on the U.S. Solar Decathlon 2015 competition site in Irvine, CA during October 2015.

\subsection{High Efficiency Photovoltaic Panels}

The Aggie Sol home features twenty-three SunPower E20-327 photovoltaic panels with a 20.4\% nominal efficiency [8], which substantially exceeds average photovoltaic panel efficiency (16.3\%) [9]. In addition to cooling the home, the night sky sprinklers perform an important second function - washing the panels and removing dust that would otherwise accumulate and reduce system efficiency by up to 40\% [10].

\section{Methods}

\subsection{Modeling the Home}

The home was modeled in BEopt [11], an energy modeling software provided by the National Renewable Energy Laboratory (NREL). A few aspects of the home, such as the radiant heating and cooling system, night sky cooling system, and Nexus graywater heat recovery system, could not be simulated in BEopt so additional calculations were made in Microsoft Excel®. BEopt allows accurate modeling of the home's floor plan but its three-dimensional modeling capabilities are limited. Fig. 1 is a photograph of the home on the U.S. DOE Solar Decathlon 2015 competition site in Irvine, CA, while Fig. 2 depicts the floor plan and 3D rendering of the house in BEopt. The final location for the competition home will be on the UC Davis campus, hence the energy model considered year-round operation in Davis, CA, under typical climate conditions.

Individual rooms cannot be modeled nor can the specific positions of windows be assigned. However, these limitations do not significantly affect the accuracy of the energy simulation because the user can manually input the surface area of each wall occupied by windows. Additionally, the Aggie Sol heating and cooling control system treats the home as a single zone so individual room loads were not considered. 

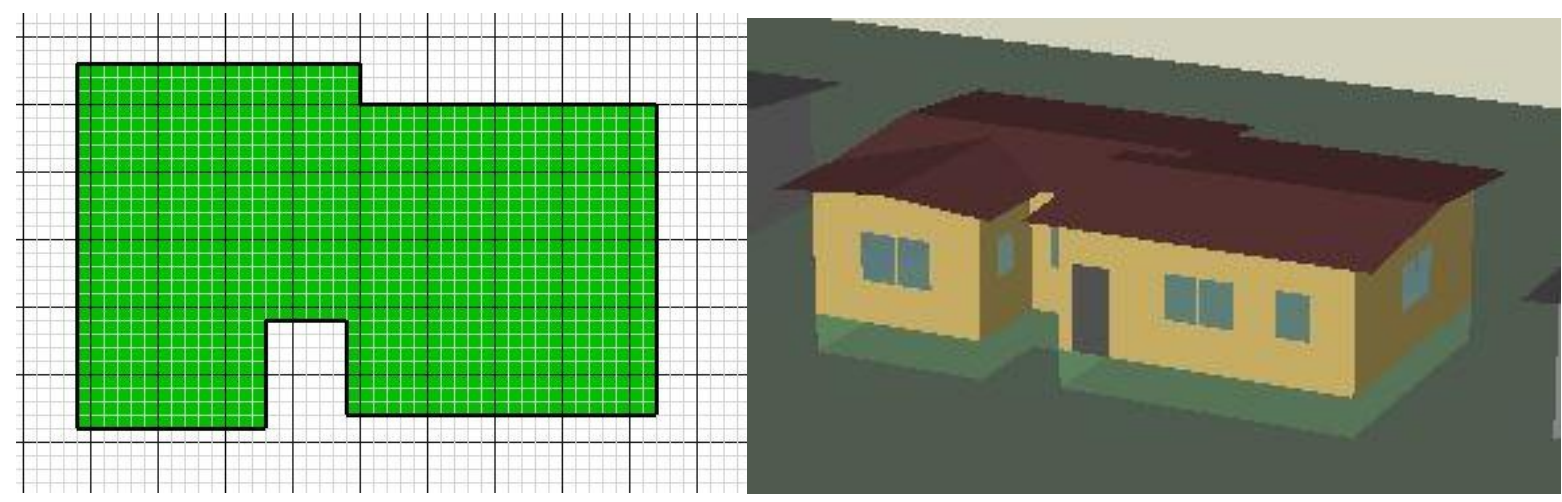

Fig 2. Aggie Sol Floor Plan and 3D Rendering in BEopt

Table 1 summarizes how construction materials, equipment and appliances were entered into BEopt to generate the energy model. Irrelevant options such as the number of gas grills, extra freezers, etc., have been omitted from this table for the sake of brevity and clarity.

Table 1

BEopt Entry Summary

\begin{tabular}{|c|c|c|}
\hline Group Name & Category Name & Option \\
\hline Building & $\begin{array}{l}\text { Orientation } \\
\text { Neighbors } \\
\text { Latitude } \\
\text { Longitude } \\
\text { Height }\end{array}$ & $\begin{array}{l}\text { South, Azimuth } 0.0^{\circ} \\
15^{\prime} \text { offset } \\
38.543574 \\
-121.763684 \\
15 \mathrm{ft}\end{array}$ \\
\hline \multirow[t]{2}{*}{ Walls } & Wood Stud & R-21 EcoBatt, 0.121 Framing Factor \\
\hline & $\begin{array}{l}\text { Wall Sheathing } \\
\text { Exterior Finish }\end{array}$ & $\begin{array}{l}\text { OSB } \\
\text { Fiber-Cement, Light }\end{array}$ \\
\hline Ceilings/Roofs & $\begin{array}{l}\text { Façade Area } \\
\text { Finished Roof } \\
\text { Roof Material }\end{array}$ & $\begin{array}{l}1325 \mathrm{ft}^{2} \\
\mathrm{R}-38 \text { EcoBatt, } 0.0381 \text { Framing Factor } \\
\text { TPO Single Ply Membrane }\end{array}$ \\
\hline Foundation/Floors & $\begin{array}{l}\text { Pier \& Beam } \\
\text { Carpet } \\
\text { Floor Area, Conditioned }\end{array}$ & $\begin{array}{l}\text { R-30 EcoBatt } \\
\text { No Carpet } \\
900 \mathrm{ft}^{2}\end{array}$ \\
\hline Thermal Mass & $\begin{array}{l}\text { Floor Mass } \\
\text { Exterior Wall Mass } \\
\text { Partition Wall Mass } \\
\text { Ceiling Mass }\end{array}$ & $\begin{array}{l}\text { 2" Gypsum Concrete } \\
\text { 1/2" Light Drywall } \\
\text { 2 X 1/2" Light Drywall } \\
\text { 1/2" Light Drywall }\end{array}$ \\
\hline \multirow[t]{3}{*}{ Windows \& Doors } & Window Areas & $\begin{array}{l}146 \mathrm{ft}^{2} \text { total windows: } \\
\text { South }=57 \mathrm{ft}^{2} \\
\text { North }=35 \mathrm{ft}^{2} \\
\text { West }=29 \mathrm{ft}^{2} \\
\text { East }=25 \mathrm{ft}^{2}\end{array}$ \\
\hline & Windows & $\begin{array}{l}\text { Double-Pane, Low-E, Metal Frame, Argon Fill } \\
\text { U-Value }=0.44 \\
\text { SHGC }=0.24\end{array}$ \\
\hline & $\begin{array}{l}\text { Interior Shading } \\
\text { Eaves } \\
\text { Overhangs }\end{array}$ & $\begin{array}{l}\text { Summer }=0.6, \text { Winter }=0.7 \\
2 \mathrm{ft} \\
\text { None }\end{array}$ \\
\hline Airflow & $\begin{array}{l}\text { Air Leakage } \\
\text { Mechanical Ventilation } \\
\text { Natural Ventilation } \\
\text { Air Source Heat Pump } \\
\text { Ducts } \\
\text { Ceiling Fan } \\
\end{array}$ & $\begin{array}{l}10 \text { ACH50 } \\
\text { Exhaust } \\
\text { Year-Round } \\
\text { SEER } 14,8.2 \text { HSPF } \\
\text { None } \\
\text { Standard Efficiency, } 3 \text { Fans }\end{array}$ \\
\hline Space Conditioning Schedules & $\begin{array}{l}\text { Cooling Set Point } \\
\text { Heating Set Point } \\
\text { Humidity Set Point }\end{array}$ & $\begin{array}{l}65^{\circ} \mathrm{F} \\
78^{\circ} \mathrm{F} \\
60 \% \text { Relative Humidity }\end{array}$ \\
\hline Water Heating & $\begin{array}{l}\text { Water Heater } \\
\text { Distribution }\end{array}$ & $\begin{array}{l}\text { HPWH, } 80 \text { Gallons } \\
\text { R-3.21. HomeRun, PEX }\end{array}$ \\
\hline Lighting & Lighting & 92.3\% Hardwired LED, 7.7\% Hardwired CFL \\
\hline \multirow[t]{2}{*}{ Appliances \& Fixtures } & $\begin{array}{l}\text { Refrigerator } \\
\text { Cooking Range } \\
\text { Dishwasher } \\
\text { Clothes Washer }\end{array}$ & $\begin{array}{l}\text { Nominal Power }=1800 \mathrm{~W} \\
\text { Nominal Power }=3600 \mathrm{~W} \\
\text { Nominal Power }=1800 \mathrm{~W} \\
\text { Nominal Power }=1800 \mathrm{~W}\end{array}$ \\
\hline & $\begin{array}{l}\text { Clothes Dryer } \\
\text { Hot Water Fixtures }\end{array}$ & $\begin{array}{l}\text { Nominal Power }=7200 \mathrm{~W} \\
0.50 \text { (half the usage of a standard BEopt home) }\end{array}$ \\
\hline Miscellaneous & Plug Loads & 0.15 ( $15 \%$ of the plug loads of a standard BEopt home) \\
\hline \multirow[t]{5}{*}{$\begin{array}{l}\text { Appliances \& Fixtures } \\
\text { Schedules }\end{array}$} & $\begin{array}{l}\text { Refrigerator Schedule } \\
\text { Cooking Range Schedule }\end{array}$ & $\begin{array}{l}\text { Standard BEOpt schedule } \\
\text { Standard BEOpt schedule }\end{array}$ \\
\hline & Dishwasher Schedule & Standard BEOpt schedule \\
\hline & Clothes Washer Schedule & Standard BEOpt schedule \\
\hline & Clothes Dryer Schedule & Standard BEOpt schedule \\
\hline & Hot Water Fixtures Schedule & Standard BEOpt schedule \\
\hline Photovoltaics & PV System & $6.5 \mathrm{~kW}$ \\
\hline
\end{tabular}




\subsection{Cost Considerations}

To attain an affordable cost, the Aggie Sol team created a "cost estimating team" under the mentorship of a professional cost estimator from Brown Construction. The cost estimating team used a RSMeans database to run several iterations of a comprehensive cost estimate which entailed all the finishes, structural framing, thermal and moisture protection, landscaping, casework, doors and windows, fixtures, and other components of the home. Each iteration was reviewed by the cost estimator. Additionally, the DOE hired a professional cost estimator from Faithful and Gould to prepare a detailed estimate, at selected stages in the design and construction process, based on a quantity take-off submitted by each team. The Aggie Sol team used the cost estimates as a guiding factor in design and construction decisions. The DOE assigned a final cost of \$249,312 to the Aggie Sol home. By comparison, the winning team, Stevens Institute of Technology, built a home with an estimated construction cost of $\$ 290,776$, Sacramento State University built a house with the highest estimated construction cost of $\$ 332,323$, and the average cost of all Solar Decathlon homes was $\$ 287,315$.

\subsection{Construction Techniques}

\subsubsection{In-Line Framing}

To achieve the lowest possible framing factor, which is the fraction of wall area occupied by wooden studs[12], while not compromising the structural integrity of the house, the Aggie Sol team utilized in-line framing. In-line framing reduces the amount of lumber by changing stud spacing from $16.0 \mathrm{in}$. $(40.6 \mathrm{~cm})$ on-center to $24.0 \mathrm{in}$. $(71.0 \mathrm{~cm})$ on-center and eliminates unnecessary headers [13].

Not only does the home feature more insulation because of in-line framing, but the insulation also has higher than normal R-values. The construction industry uses R-values $\left(\frac{h r * f t^{2} *^{\circ} \mathrm{F}}{B T U-i n}\right)$ to measure the ability of insulation to reduce heat transfer [3]. The Aggie Sol home uses Eco-Batt, a recycled fiberglass batt insulation manufactured by Knauf Insulation [14] in the floor, wall and roof cavities, with R-values substantially higher than those used in conventional framing [15] - Table 2 compares Aggie Sol insulation to conventional insulation modeled by the BEopt benchmark case [12].

Table 2

Aggie Sol Home Insulation vs Conventional Insulation.

\begin{tabular}{llll}
\hline Category & Aggie Sol Home & & Conventional Home \\
\hline & Type & Thickness (in) & Type \\
\hline Floor Insulation & R-30 EcoBatt & 10 & R-19 Fiberglass Batt \\
Wall Insulation & R-21 EcoBatt & 5.5 & R-13 Fiberglass Batt \\
Roof Insulation & R-38 EcoBatt & 12 & R-30C Fiberglass Batt \\
\hline
\end{tabular}

\subsubsection{Low Window to Wall Ratio}

The window industry rates thermal transmittance with the U-factor[3], which is measured in $\frac{B T U}{f t^{2} * h r *^{\circ} F}$, and rates solar heat gain with the solar heat gain coefficient (SHGC), which is the ratio of total solar heat passing through the glass to solar heat falling on the glass at a 90 ${ }^{\circ}$ angle [3]. The BEopt analysis compares two cases, "Aggie Sol Home" and "Conventional Windows." The only modeling difference is the window selection. The conventional home features a $15 \%$ window to wall ratio with the windows equally distributed on all four walls. These windows have a mean U-factor and SHGC of 0.37 and 0.3, respectively. The Aggie Sol home has a much smaller window to wall ratio-only 9.2\% and the window areas are distributed unequally. The south wall contains $39 \%$ of the home's window area to maximize passive heating during the winter [16]. Finally, the mean U-factor and SHGC were 0.44 and 0.24 , respectively [17].

\subsubsection{Thermal Mass}

The Aggie Sol home has under-floor gypsum concrete as thermal mass in close conjunction with the radiant heating and cooling system. When the house is in heating mode, the hot water running through the radiant system is significantly hotter than the gypsum concrete-as a result, the gypsum concrete absorbs a substantial quantity of heat. The floor can keep the home warm even after the thermostat has switched off the radiant pump because the gypsum concrete releases the absorbed heat [18]. In cooling mode, the gypsum concrete acts in reverse, losing heat to the much cooler water running through the radiant system. After the thermostat switches off the radiant pump, the cold slab continues to cool the home by absorbing heat from the warmer room [19].

\subsection{Appliance Selection}

Choosing energy efficient appliances is critical to maximizing energy savings. However, Team Aggie Sol wanted to choose appliances that were not only energy efficient, but also water efficient, aesthetically pleasing, readily available for purchase (to avoid long lead times during construction), and affordable. We consulted EnergyStar $[20,21]$ to obtain spreadsheets containing data on dishwashers, refrigerators, clothes washers, and televisions. Before utilizing our appliance scoring methodology, we considered the following selection criteria:

(1) Dishwashers-American Disabilities Act (ADA) compliant, Energy Star compliant, counter-depth

(2) Refrigerators-ADA compliant, counter-depth, total capacity exceeding $16 \mathrm{ft}^{3}\left(0.45 \mathrm{~m}^{3}\right)$

(3) Clothes washers-ADA compliant, counter-depth, stackable. We selected a clothes dryer that matched the washer.

(4) Televisions - 50 in $(127 \mathrm{~cm})$ screen size, vertical resolution of 1080p

\subsubsection{Modeling Conventional Appliances in BEopt}


2.4.2. As the basis of comparison with the Aggie Sol appliances, we considered the benchmark dishwasher, refrigerator, clothes washer, dryer, hot water, and cooking range in BEopt as our "conventional appliances." Although BEopt does not directly model televisions, it does account for home electronics and miscellaneous appliances with its "Plug Loads" feature. All of the benchmark BEopt appliances are based on research performed by Building America [12]. The usage rate of each appliance was modeled with the corresponding standard BEopt schedule-BEopt breaks down daily energy usage into 2.4.3. hourly increments based on the likelihood that the appliance is in operation during a given hour.

Cooking Range

2.4.4.

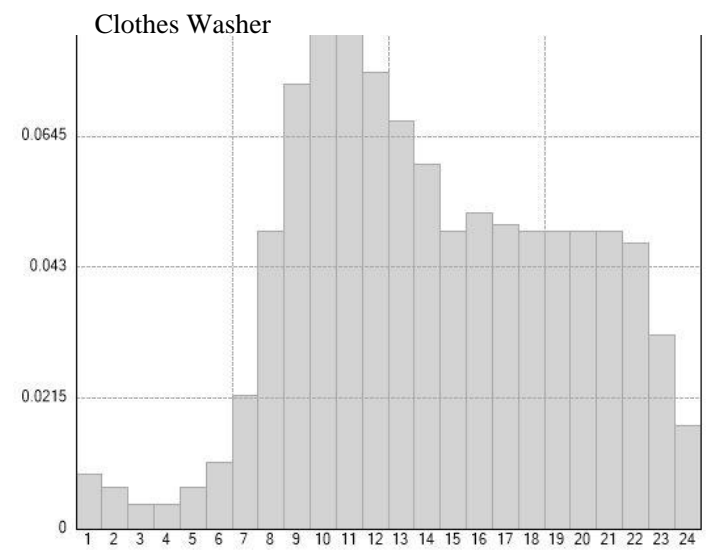

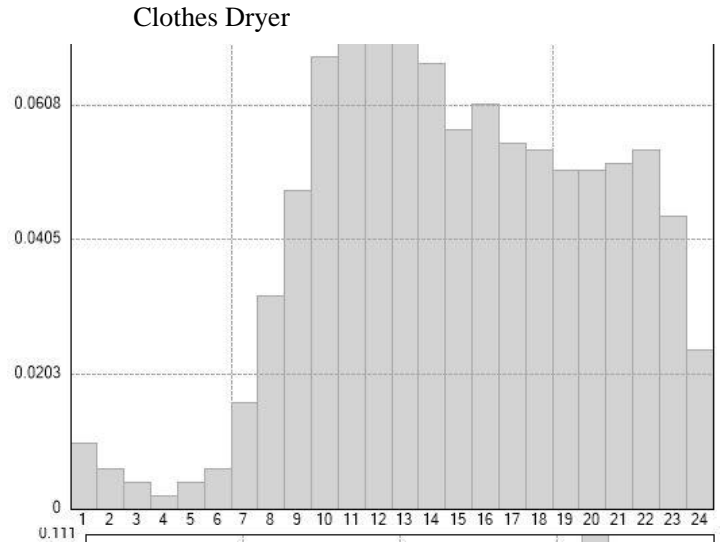

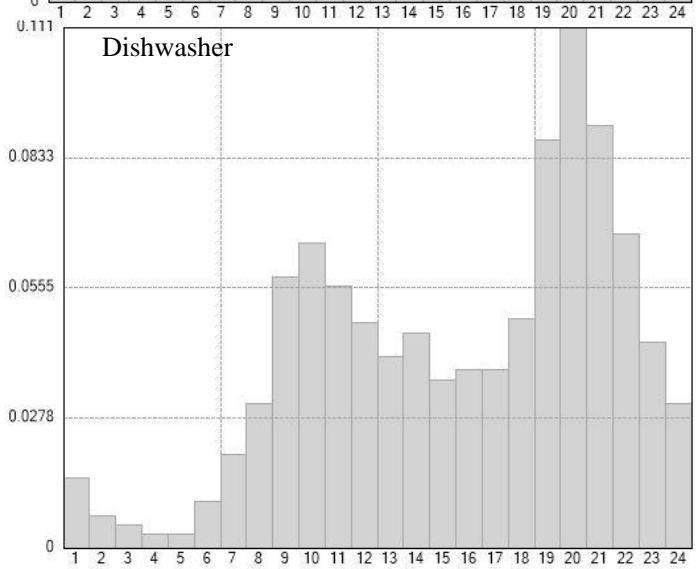

Fig. 3 provides the hourly usage profiles for the team's appliances (refrigerator, clothes washer, clothes dryer, dishwasher, cooking range, and hot water).

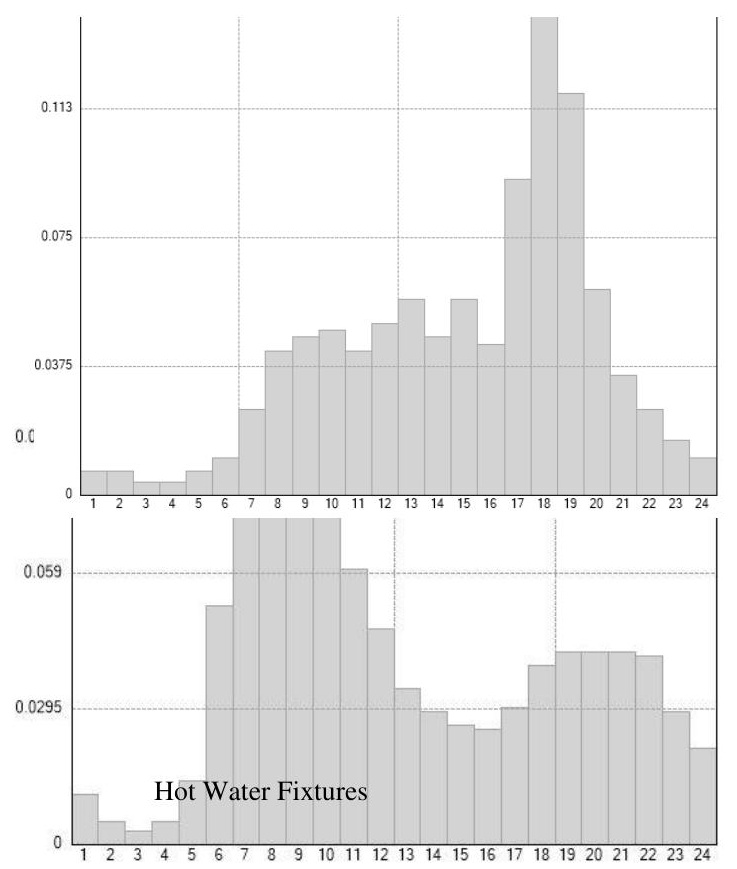


Fig. 3. BEopt Appliance Schedules

\subsubsection{Exceptions to the Appliance Scoring Methodology}

The appliance scoring methodology was not applied to the cooking range because annual electricity consumption data was not available from Energy Star for residential cooking appliances. Team Aggie Sol selected a slide-in, ADA compliant cooking range, Frigidaire LFES3025PF [22] based on aesthetics and cost. This model is a regular electric cooking range-BEopt indicates that the more energy-efficient alternative, an electric induction oven, consumes only $27 \mathrm{KWh}$ per year less than an equivalent non-induction model.

Additionally, since the washer and dryer needed to be bought together, their combined cost, availability and aesthetic appeal, as opposed to those of the washer alone, were considered in the analysis. The energy usage of the dryer was not considered in the analysis because at the time of the analysis, annual electricity consumption data was not available from Energy Star.

\subsubsection{Appliance Scoring Methodology}

To evaluate these five parameters, (1) $\mathrm{E}=$ energy efficiency, (2) $\mathrm{W}=$ water efficiency, (3) $\mathrm{C}=$ cost, (4) $\mathrm{A}=$ availability, (5) and $\mathrm{L}=$ aesthetic appeal, Team Aggie Sol developed an appliance scoring methodology to rate each appliance from 0 to 10 in each respective parameter, with 0 being the lowest and 10 being the highest score:

(1) $E$ was categorized by annual electricity consumption in $\mathrm{kWh}$.

(2) $W$ was categorized by annual water consumption in gallons. In the case of refrigerators and televisions, which do not consume water, water efficiency was disregarded.

(3) $C$ was categorized by manufacturer suggested retail price (MSRP) in dollars.

(4) A was categorized by the ease with which the appliance could be procured in the United States. Appliances not available in the United States were assigned a zero, appliances not available at a local retailer but available via shipping were assigned a 5, and appliances ready for pick-up at local retailers were assigned a 10.

(5) $L$ was determined by our design team, who assigned a score from 0 to 10.

To achieve a continuous scoring spectrum from 0 to 10 , the energy efficiency, water efficiency, and cost of the appliances had to be normalized. As an example, the normalization process for assigning a cost score to dishwashers is illustrated in Table 3 (in reality 43 dishwashers were scored, but for simplicity the example below shows only five dishwashers).

Table 3

\begin{tabular}{lccl} 
Example of the Normalization Process for Dishwashers \\
\hline Model \# & Appliance ID & Cost (MSRP, \$) & Score \\
\hline Bosch SHX68E15UC [21] & 1 & $1,249.00$ & 0.00 \\
Bosch SGE63E06UC [23] & 2 & 809.99 & 5.17 \\
Whirlpool WDF750SAYB [21] & 3 & 400 & 10.00 \\
Bosch SHV68E13UC [21] & 4 & $1,249.00$ & 0.00 \\
Bosch SHX98M09UC [21] & 5 & 1,099 & 1.77 \\
\hline
\end{tabular}

Let $X_{i}$ and $C_{i}$ represent the cost (\$) and cost score, respectively, of the dishwasher with appliance ID “i." $X_{\min }$ and $X_{\max }$ represent the costs of the least and most expensive dishwashers, respectively. Then:

$C_{i}=\left(X_{i}-X_{\max }\right) /\left(X_{\min }-X_{\max }\right) * 10$

$\left.C_{1}=(1249.00-1249) /(400-1249)\right) * 10=0$

$C_{3}=\frac{400-1249}{400-1249} * 10=10$

Note that since lower cost, energy consumption, and water consumption are desirable, these parameters result in higher scores. After normalization, weighting factors were assigned to each of the scores to obtain an overall pre-aesthetic score. To evaluate the viability of appliances under different circumstances, three sets of weighting factors were assigned: 
(1) All parameters were treated equally.

(2) Affordability is weighted double the other parameters

(3) Affordability and energy efficiency are weighted double the other parameters.

\section{Table 4}

Appliance Scoring Criteria

\begin{tabular}{|c|c|c|c|}
\hline Appliance & \multicolumn{3}{|c|}{ Weighting Scenarios } \\
\hline Scenario & (1) All Parameters Equal & (2) Affordability Double & (3) Affordability and Energy Double \\
\hline Dishwasher & $\mathrm{W}_{\mathrm{A}}=\mathrm{W}_{\mathrm{C}}=\mathrm{W}_{\mathrm{E}}=\mathrm{W}_{\mathrm{L}}=\mathrm{W}_{\mathrm{W}}=1 / 5$ & $\begin{array}{l}\mathrm{W}_{\mathrm{A}}=\mathrm{W}_{\mathrm{E}}=\mathrm{W}_{\mathrm{L}}=\mathrm{W}_{\mathrm{W}}=1 / 6 \\
\mathrm{~W}_{\mathrm{C}}=1 / 3\end{array}$ & $\begin{array}{l}\mathrm{W}_{\mathrm{A}}=\mathrm{W}_{\mathrm{L}}=\mathrm{W}_{\mathrm{W}}=1 / 7 \\
\mathrm{~W}_{\mathrm{C}}=\mathrm{W}_{\mathrm{E}}=2 / 7\end{array}$ \\
\hline Clothes washer & $\mathrm{W}_{\mathrm{A}}=\mathrm{W}_{\mathrm{C}}=\mathrm{W}_{\mathrm{E}}=\mathrm{W}_{\mathrm{L}}=\mathrm{W}_{\mathrm{W}}=1 / 5$ & $\begin{array}{l}\mathrm{W}_{\mathrm{A}}=\mathrm{W}_{\mathrm{E}}=\mathrm{W}_{\mathrm{L}}=\mathrm{W}_{\mathrm{W}}=1 / 6 \\
\mathrm{~W}_{\mathrm{C}}=1 / 3\end{array}$ & $\begin{array}{l}\mathrm{W}_{\mathrm{A}}=\mathrm{W}_{\mathrm{L}}=\mathrm{W}_{\mathrm{W}}=1 / 7 \\
\mathrm{~W}_{\mathrm{C}}=\mathrm{W}_{\mathrm{E}}=2 / 7\end{array}$ \\
\hline Television & $\mathrm{W}_{\mathrm{A}}=\mathrm{W}_{\mathrm{C}}=\mathrm{W}_{\mathrm{E}}=\mathrm{W}_{\mathrm{L}}=1 / 4$ & $\begin{array}{l}\mathrm{W}_{\mathrm{A}}=\mathrm{W}_{\mathrm{E}}=\mathrm{W}_{\mathrm{L}}=1 / 5 \\
\mathrm{~W}_{\mathrm{C}}=2 / 5\end{array}$ & $\begin{array}{l}\mathrm{W}_{\mathrm{A}}=\mathrm{W}_{\mathrm{L}}=1 / 6 \\
\mathrm{~W}_{\mathrm{C}}=\mathrm{W}_{\mathrm{E}}=1 / 3\end{array}$ \\
\hline Refrigerator & $\mathrm{W}_{\mathrm{A}}=\mathrm{W}_{\mathrm{C}}=\mathrm{W}_{\mathrm{E}}=\mathrm{W}_{\mathrm{L}}=1 / 4$ & $\begin{array}{l}\mathrm{W}_{\mathrm{A}}=\mathrm{W}_{\mathrm{E}}=\mathrm{W}_{\mathrm{L}}=1 / 5 \\
\mathrm{~W}_{\mathrm{C}}=2 / 5\end{array}$ & $\begin{array}{l}\mathrm{W}_{\mathrm{A}}=\mathrm{W}_{\mathrm{L}}=1 / 6 \\
\mathrm{~W}_{\mathrm{C}}=\mathrm{W}_{\mathrm{E}}=1 / 3\end{array}$ \\
\hline
\end{tabular}

The weighting factors are as follow:

$W_{A}=$ Availability weighting factor

$W_{C}=$ Affordability weighting factor

$W_{E}=$ Energy Efficiency weighting factor

$W_{L}=$ Aesthetics weighting factor

$W_{w}=$ Water Efficiency weighting factor

The pre-aesthetic scoring equation is as follows:

Pre-Aesthetic Score $=X_{A} W_{A}+X_{C} W_{C}+X_{E} W_{E}+X_{W} W_{w}$

The design team reviewed the appliances with the top ten pre-aesthetic scores under each weighting scenario. The design team then assigned an aesthetic score to these appliances, after which the appliances were re-ranked with the overall scoring equation:

Overall Score $=X_{A} W_{A}+X_{C} W_{C}+X_{E} W_{E}+X_{L} W_{L}+X_{W} W_{w}$

Table 5 and Table 6 summarize the appliances with the highest overall scores under each weighting scenario. At first glance, one notices that most of the top scorers remain the same under each scenario- this phenomenon occurs because the top scoring appliance is usually substantially more energy efficient and water efficient than its counterparts. However, for any given appliance, the $2^{\text {nd }}$ to $10^{\text {th }}$ ranks change significantly depending on the weighting scenario-for example, compare the list of top ten dishwashers under scenarios (1), (2), and (3) in Table 6.

Table 5

Final Appliance Selections.

\begin{tabular}{llll}
\hline Appliance & Scenario 1 & Scenario 2 & Scenario 3 \\
\hline Dishwasher & Bosch SGE6306UC [24] & Bosch SHV68E13UC[21] & Bosch SHV68E13UC \\
Clothes Washer & Frigidaire FFW5000QW [25] & Frigidaire FFW5000QW & Frigidaire FFW5000QW \\
Clothes Dryer & Frigidaire FFQE5000QW [26] & Frigidaire FFQE5000QW & Frigidaire FFQE5000QW \\
Television & Samsung UN58H5005AF [27] & Samsung UN58H5005AF & Samsung UN58H5005AF \\
Refrigerator & Frigidaire FFHT1831QS [28] & Frigidaire FFHT1831QS & Frigidaire FFHT1831QS \\
\hline
\end{tabular}

Table 6

Energy Use, Water Use, and Cost of Aggie Sol Appliances

\begin{tabular}{lllll}
\multicolumn{2}{l}{ Energy Use, Water Use, and Cost of Aggie Sol Appliances } & & \\
\hline Appliance & Model \# & $\begin{array}{l}\text { Energy Use } \\
(\mathrm{kWh} / \mathrm{year})\end{array}$ & $\begin{array}{l}\text { Water Use (gallons } \\
{[\mathrm{L}] / \text { cycle) }}\end{array}$ & Cost (\$) \\
\hline Dishwasher & Bosch SGE6306UC [24] & 234 & $4.5[17.0]$ & 649.00 \\
Clothes Washer & Frigidaire FFW5000QW [29] & 96 & $18[68.1]$ & 656.00 \\
Clothes Dryer & Frigidaire FFQE5000QW [26] & Not Available & Not Applicable & 829.00 \\
Television & Samsung UN58H5005AF [30] & 73 & Not Applicable & 599.99 \\
Refrigerator & Frigidaire FFHT1831QS [28] & 363 & Not Applicable & 929.00 \\
\hline
\end{tabular}

\subsection{Heating and Cooling System}

\subsubsection{Controls}

The Aggie Sol home features a control system that is inexpensive and draws less than 2 W [31], [32], [33], [34]. It allows two pumps operating on independent series circuits, to circulate hot and chilled water as needed. When the indoor temperature rises above the cooling set point, the thermostat sends a 24 volt signal to the Taco sentry cooling zone valve [32]. When the indoor temperature falls below the heating set point, the thermostat sends a 24 volt signal to the heating zone valve. Each zone valve consists of a mechanical valve and an electronic actuator 
[32]. The electronic actuator closes a series circuit that terminates at the radiant pump, thereby activating the pump, while the mechanical valve opens the pipe and allows water to flow downstream to the radiant pump. The pump then circulates water through the under-floor radiant loops.

The night sky control system also uses a series circuit, which consists of a Honeywell RPLS730B time clock [31] directly connected to the electrical panel, an ETC Ranco 111000 temperature sensor (aquastat) [33], and the Armstrong E.212 night sky pump [35]. The time clock allows the resident to set a specific timeframe of operation of the aquastat [19]. When $\mathrm{T}_{\mathrm{CWST}}$ rises above the user-defined set-point, the aquastat's microprocessor closes the switch between itself and the night sky pump, thereby activating the pump. The night sky pump then delivers water to the rooftop sprinklers for as long as necessary to reach the CWST's set point temperature.

\subsubsection{Radiant System Theory}

The nature of heat delivery in radiant systems allows the occupant to feel comfortable over a larger air temperature range than forced air systems [36]. Allowing air temperature to fluctuate over a larger range reduces the operation time of the heating and cooling system, which in turn decreases the energy used to heat and cool the home.

Four factors influence a home's ability to control human thermal comfort: air temperature, radiant temperature, humidity, and air velocity [37]. Conventional heating and cooling systems control air temperature, humidity, and air velocity, but neglect radiant temperature. Radiant systems, however address radiant temperature, which contributes to their efficiency. Mean radiant temperature $T_{r}$ can be thought of as the areaweighted average temperature of all surfaces enclosing an occupant [38]:

$T_{r}=\frac{T_{1} A_{1}+T_{2} A_{2}+\cdots+T_{N} A_{A N}}{A_{1}+A_{2}+\cdots+A_{N}}$

By combining $T_{r}$ and $T_{a}$, one obtains the operative temperature, $\theta$, the temperature that the occupant feels [38]:

$\theta=\frac{\left(h_{c} * T_{a}\right)+\left(h_{r} * T_{r}\right)}{h_{c}+h_{r}}$

Where:

$T_{a}=$ air temperature $\left({ }^{\circ} \mathrm{F}\right)$
$h_{c}=$ convective coefficient for the human body $\left(\frac{B t u}{h * f t^{2} *^{\circ} \mathrm{F}}\right)$
$h_{r}=$ radiant coefficient for the human body $\left(\frac{B t u}{h * f t^{2} *^{\circ} \mathrm{F}}\right)$

In practice, the equation can be simplified as [38]:

$\theta_{f, i}=\left(T_{a}+T_{r}\right) / 2$

This simplification is valid as long as the difference in the air and mean radiant temperatures remains less than $7.0^{\circ} \mathrm{F}\left(3.9^{\circ} \mathrm{C}\right)$ and the air velocity is below $0.2 \mathrm{~m} / \mathrm{s}$ [38].

Radiant systems address both temperature variables present in the operative temperature equation (Eq. 7) while forced air systems do not. As a result, the comfortable indoor air temperature range increases substantially. The heating and cooling set points can go as low as $65.0^{\circ} \mathrm{F}$ $\left(18.3^{\circ} \mathrm{C}\right)[39]$ and as high as $78.0^{\circ} \mathrm{F}\left(25.6^{\circ} \mathrm{C}\right)[38]$. By contrast, the typical forced air heating and cooling set points are $71.0^{\circ} \mathrm{F}\left(21.7^{\circ} \mathrm{C}\right)$ and $76.0^{\circ} \mathrm{F}\left(24.4^{\circ} \mathrm{C}\right)$, respectively [12].

Two other factors contribute to the energy efficiency of the radiant system: replacing ductwork with cross-linked polyethylene (PEX) or high-density polyethylene (HDPE) tubing and substituting water for air. Heat loss in ductwork can be as high 25-40\% before the air is delivered to a room [40]. Additionally, air has poor heat retention - the specific heat of air is $1.005 \mathrm{~J} / \mathrm{g}^{\circ} \mathrm{C}$ at $25^{\circ} \mathrm{C}$ [41] while water has a specific heat of $4.18 \mathrm{~J} / \mathrm{g}^{\circ} \mathrm{C}$ at $25{ }^{\circ} \mathrm{C}$ [42]. Water also is much denser than air $\left(1000 \mathrm{~kg} / \mathrm{m} 3\right.$ at $25^{\circ} \mathrm{C}$ [42] vs $1.165 \mathrm{~kg} / \mathrm{m}^{3}$ at $\left.25^{\circ} \mathrm{C}\right)$ [41]. Thus, a given volume of water can hold about 3,450 times as much heat as an equivalent volume of air.

\subsubsection{Radiant System Design}

To reduce the cost of the controls, the home was treated as a single zone. This zone consists of eight radiant loops, each approximately $200 \mathrm{ft}$ long $(61.0 \mathrm{~m})$ - Fig. 4 illustrates these loops. Heat transfer occurs continuously along the length of the loop. HDPE tubing with $1 / 2$ in. $(1.3 \mathrm{~cm})$ inner diameter was spaced 6.0 in. $(15.2 \mathrm{~cm})$ on-center. Each loop was designed to receive a flow rate of 1 gallon per minute (GPM) (0.0038 $\mathrm{m}^{3} / \mathrm{min}$ ). Thus, the radiant pump was sized to deliver $8 \mathrm{GPM}\left(0.030 \mathrm{~m}^{3} / \mathrm{min}\right)$ to the radiant system and to overcome 11.5 psi (pounds per square inch) or 1.38 bar of head loss. For this task, the Taco 008 circulator, which draws only $1 / 25 \mathrm{hp}(0.93 \mathrm{~kW})$ [43], was selected. 


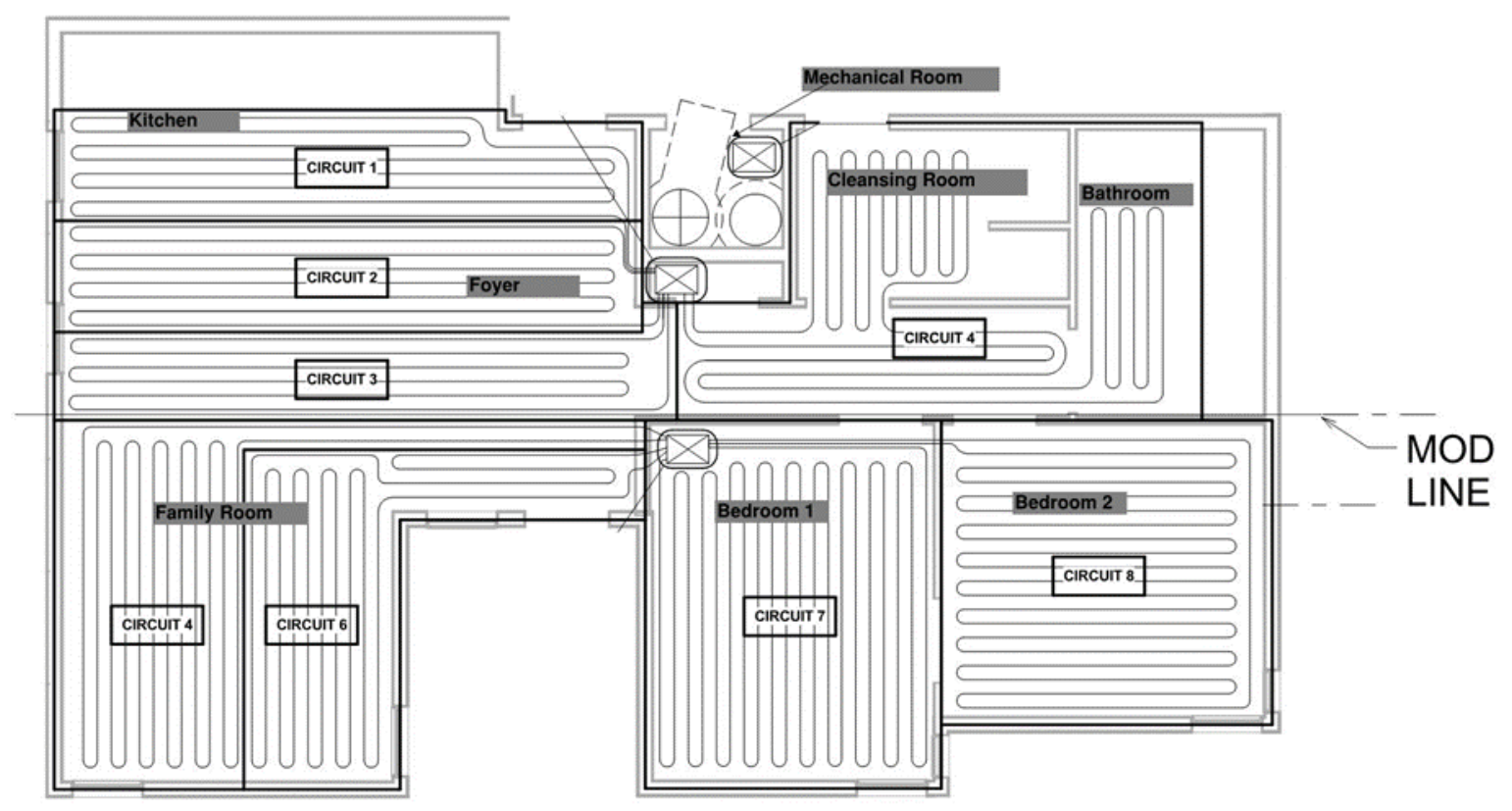

Fig. 4. Radiant Loops

\subsection{Heating and Cooling Energy Calculations}

\subsubsection{Conventional Heating and Cooling System: Forced Air Distribution}

The default forced air distribution system in BEopt served as the basis of comparison with the Aggie Sol heating system. All default parameters in BEopt are recommendations based on research performed by the DOE's Building America program [12]. Building America recommended a $71.0^{\circ} \mathrm{F}\left(21.7{ }^{\circ} \mathrm{C}\right)$ heating set-point and a $76.0^{\circ} \mathrm{F}\left(24.4^{\circ} \mathrm{C}\right)$ cooling set-point [12]. Building America also suggested modeling a forced air distribution system with R-8 insulated ducts that experience $30 \%$ system energy losses. A gas furnace with an annual fuel utilization energy of $78 \%$ served as the heating source for the home. In cooling mode, the BEopt forced air distribution system involved a central air conditioner with a seasonal efficiency energy ratio (SEER) of 10 and an air handler that provided 386.1 cubic feet per minute, CFM, (10.9 $\mathrm{m}^{3} / \mathrm{min}$ ) of air/ton of cooling.

\subsubsection{Aggie Sol Heating System: Radiant Heating and State HPWH}

The heating energy for the Aggie Sol radiant heating system was calculated with Microsoft Excel ® because BEopt cannot model radiant systems nor can it account for the operation of heat pump water heaters (HPWH) for a use other than domestic hot water production. To minimize electricity consumption, the 50 gallon State HPWH was operated primarily in heat pump mode. The State HPWH has a DOE rated energy factor (EF) of 2.78 [2]. However, this EF is only valid at the temperature difference measured by the DOE test—an air temperature of $67.5^{\circ} \mathrm{F}\left(19.7^{\circ} \mathrm{C}\right)$, where the air functions as the heat source, and a tank temperature of $135.0^{\circ} \mathrm{F}\left(57.2^{\circ} \mathrm{C}\right)$, where the tank functions as the heat sink [44]. The temperature difference of the Aggie Sol radiant system is $52.7^{\circ} \mathrm{F}\left(11.5^{\circ} \mathrm{C}\right)$ - the mean ambient air temperature in Davis during the heating season is $52.3{ }^{\circ} \mathrm{F}\left(11.3{ }^{\circ} \mathrm{C}\right)$ and the radiant supply temperature is $105.0^{\circ} \mathrm{F}\left(40.6{ }^{\circ} \mathrm{C}\right)$. To evaluate the EF of the State HPWH at a temperature difference of $52.7^{\circ} \mathrm{F}\left(11.5^{\circ} \mathrm{C}\right)$ we developed an empirical equation based on the NEEA's Northern Climate Energy Factor Test [45]:

$E F_{\text {compressor }}=-0.0271\left(T_{a}-T_{H P W H}\right)+4.6847$

The State HPWH has a compressor nominally rated at $0.49 \mathrm{~kW}$ [46]. The heat transfer capacity of any heat pump depends on the power draw and $\mathrm{EF}$ of its compressor [47]:

Capacity $\left(\frac{B t u}{h r}\right)=$ Power Draw $* E F_{\text {compressor }} * \frac{3412.12 \text { Btu }}{k W}$

Thus, the State HPWH has an EF of 3.54 when the compressor alone is active while its EF during resistance heating is 0.89 [2]. To obtain the effective $\mathrm{EF}$ for the entire heating season, the weighted average was taken of the operating hours for the compressor alone, $\mathrm{OH}_{\text {compressor }}$ and the compressor and resistance element working together, $\mathrm{OH}_{\text {combined }}$ :

$E F_{\text {effective }}=\frac{E F_{\text {compressor }} O H_{\text {compressor }}+E F_{\text {resistance }} O H_{\text {combined }}}{O H_{\text {compressor }}+O H_{\text {combined }}}$ 
To obtain the annual energy consumption of the State $\mathrm{HPWH}, \mathrm{EF}_{\text {effective }}$ was divided into the annual heating load:

Annual HPWH Energy $=\frac{\text { Annual Heating Load }}{E F_{\text {effective }}}$

The radiant pump's annual energy use is the product of its hourly power draw and the operating hours of the HPWH, $\mathrm{OH}_{\text {total }}$ :

Radiant Pump Energy $=$ Power Draw $* \mathrm{OH}_{\text {total }}$

Then the annual heating energy becomes the sum of the electricity usage of the HPWH and the radiant pump, as the controls use less than 2 $\mathrm{W}$ [33], [34], and [31]:

Heating Energy $=$ HPWH Energy + Radiant Pump Energy

\subsubsection{Night Sky Cooling System}

The Aggie Sol home features a night sky cooling system originally patented and developed as the "Cool Storage Roof" [48]. Our night sky cooling system employs conventional lawn sprinklers to spray the water stored in an insulated CWST into a thin mist that spreads across the roof surface. The flow rate into the sprinkler system was $1 \mathrm{GPM}$ for $100 \mathrm{ft}^{2}\left(9.3 \mathrm{~m}^{2}\right)$ of sprinkler coverage area [47]. Since the Aggie Sol roof has a coverage area of roughly $800 \mathrm{ft}^{2}\left(74.3 \mathrm{~m}^{2}\right)$, the design flow rate is $8.0 \mathrm{GPM}\left(0.030 \mathrm{~m}^{3} / \mathrm{min}\right)$. To minimize overspray, the design accounted for a $3 \mathrm{ft}(0.9 \mathrm{~m})$ clearance space around the roof perimeter. The night sky cooling system loses heat primarily by radiation to the clear night sky, although evaporation and convection also contribute to the cooling effect [48]. After cooling, water collects in the gutter, enters the downspout, where a cartridge filter removes particulates, and finally returns to the CWST. [47]

Radiative cooling to the sky occurs when the effective sky temperature, $T_{\text {sky }}$, is lower than the temperature of the rooftop water. $T_{\text {sky }}$, is usually below the ambient air temperature $\mathrm{T}_{\mathrm{a}}$ because atmospheric temperature falls with increasing elevation [48]. $\mathrm{T}_{\text {sky }}$ is a function of the clear sky emissivity, $\mathrm{e}_{\text {sky }}$, and $\mathrm{T}_{\mathrm{a}}[49]$ :

$$
T_{s k y}=\varepsilon_{s k y}^{0.25} T_{a}
$$

The clear sky emissivity is in turn a function of the dew point temperature $\mathrm{T}_{\mathrm{dp}}[50]$ :

$\varepsilon_{s k y}=0.711+0.56\left(\frac{T_{d p}}{100}\right)+0.73\left(\frac{T_{d p}}{100}\right)^{2}$

$\mathrm{Q}_{\mathrm{rad}}$ represents radiative heat loss in $\mathrm{W} / \mathrm{m}^{2}$ to the night sky, where $\varepsilon_{\mathrm{r}}$ is the emissivity of the water, $\mathrm{T}_{\text {pond }}$ is the temperature of the water, and $\sigma$ is the Stefan-Boltzmann constant [51].

$Q_{\text {rad }}=\varepsilon_{r}\left(\sigma T_{\text {pond }}^{4}-\sigma T_{\text {sky }}^{4}\right)$

Thus the driving force behind the night sky cooling system is the temperature gradient between the night sky and the roof "pond." Since Davis generally has clear skies, low dew point, and cool ambient temperatures during summer nights, the temperature gradient is large enough to eliminate a conventional air conditioning system.

The controls of the night sky system draw less than $1 \mathrm{~W}$ [31] and [33] so the energy usage is purely a product of the pump power draw and the number of spray hours:

$E_{\text {nightsky }}=$ Night Sky Pump Power $(k W) *$ Spray Hours

The temperature of the CWST at any time increment $\mathrm{i}, \mathrm{T}_{\mathrm{CWST}}$, is a function of the cooling load delivered by the radiant system, heat transfer with ambient air through the tank walls, and the heat dissipated through convection, evaporation, and radiation with the sky during the operation of the night sky system:

$T_{C W S T_{i}}=T_{C W S T_{i-1}}+\frac{Q_{\text {conv }}+Q_{\text {evap }}+Q_{\text {rad }}+Q_{a}+\text { Cooling Load }}{8.33 \frac{\mathrm{lb}}{\mathrm{gal}} * 60 \frac{\mathrm{min}}{\mathrm{hr}} * 8 \frac{\mathrm{gal}}{\mathrm{min}} * 1 \frac{\mathrm{BTU}}{\mathrm{F} * l b * h r}}$

Since the terms $\mathrm{Q}_{\text {conv }}, \mathrm{Q}_{\text {evap }}$, $\mathrm{Q}_{\mathrm{rad}}$, and $\mathrm{Q}_{\mathrm{a}}$ must be calibrated empirically, simulating $\mathrm{T}_{\mathrm{CwST}}$ is beyond the scope of this analysis. However, the inventor of the night sky system indicated that a $\mathrm{T}_{\mathrm{CWST}}$ of $55.0^{\circ} \mathrm{F}\left(12.8^{\circ} \mathrm{C}\right)$ is sufficient to handle typical Davis cooling loads [47]. Additionally, since $\mathrm{T}_{\text {sky }}$ is lowest between $11 \mathrm{PM}$ and $7 \mathrm{AM}$, the night sky sprinklers will only run within this timeframe. On many nights, $\mathrm{T}_{\mathrm{CWST}}$ will drop to $55.0^{\circ} \mathrm{F}\left(12.8^{\circ} \mathrm{C}\right)$ without a full 8-hour cycle, and the controls will shut off the night sky pump to save energy. A $\mathrm{T}_{\mathrm{CwsT}}$ below $55.0^{\circ} \mathrm{F}\left(12.8^{\circ} \mathrm{C}\right)$ could prove detrimental to the gypsum concrete floor - the cold water in the radiant pipes could cause condensation on the outside surface of the pipes, thereby corroding the gypsum concrete [47]. To estimate $\mathrm{E}_{\text {nightsky }}$ without computing $\mathrm{T}_{\mathrm{CWST}}$, we assumed 4 hours of spray when the daily cooling load is between 0 and 10,000 BTU (10.6 MJ). If the daily cooling load exceeds 10,000 BTU (10.6 MJ), we assumed the full 8 hour-cycle.

\subsection{Nexus Graywater Heat Recovery System}

The Aggie Sol house relied on the Nexus graywater heat recovery system, which captures heat from graywater to produce domestic hot water. The system consists of two main components, the NEXcollector, and the NEXheater [7]. The home's graywater collects in the NEXcollector, where a steel plate heat exchanger delivers its heat to R-410 refrigerant [6]. This refrigerant then travels through copper tubing to 
the NEXheater [4]. The heat delivered by the refrigerant combined with the waste heat from the heater's compressor, warm up incoming cold water by $65.0^{\circ} \mathrm{F}\left(36.1^{\circ} \mathrm{C}\right)$. Electricity then supplements the remaining heating requirement to produce $125.0^{\circ} \mathrm{F}$ (51.7 $\left.{ }^{\circ} \mathrm{C}\right)$ hot water for domestic use [7]. Fig. 5 provides a conceptual schematic of the Nexus graywater heat recovery system.

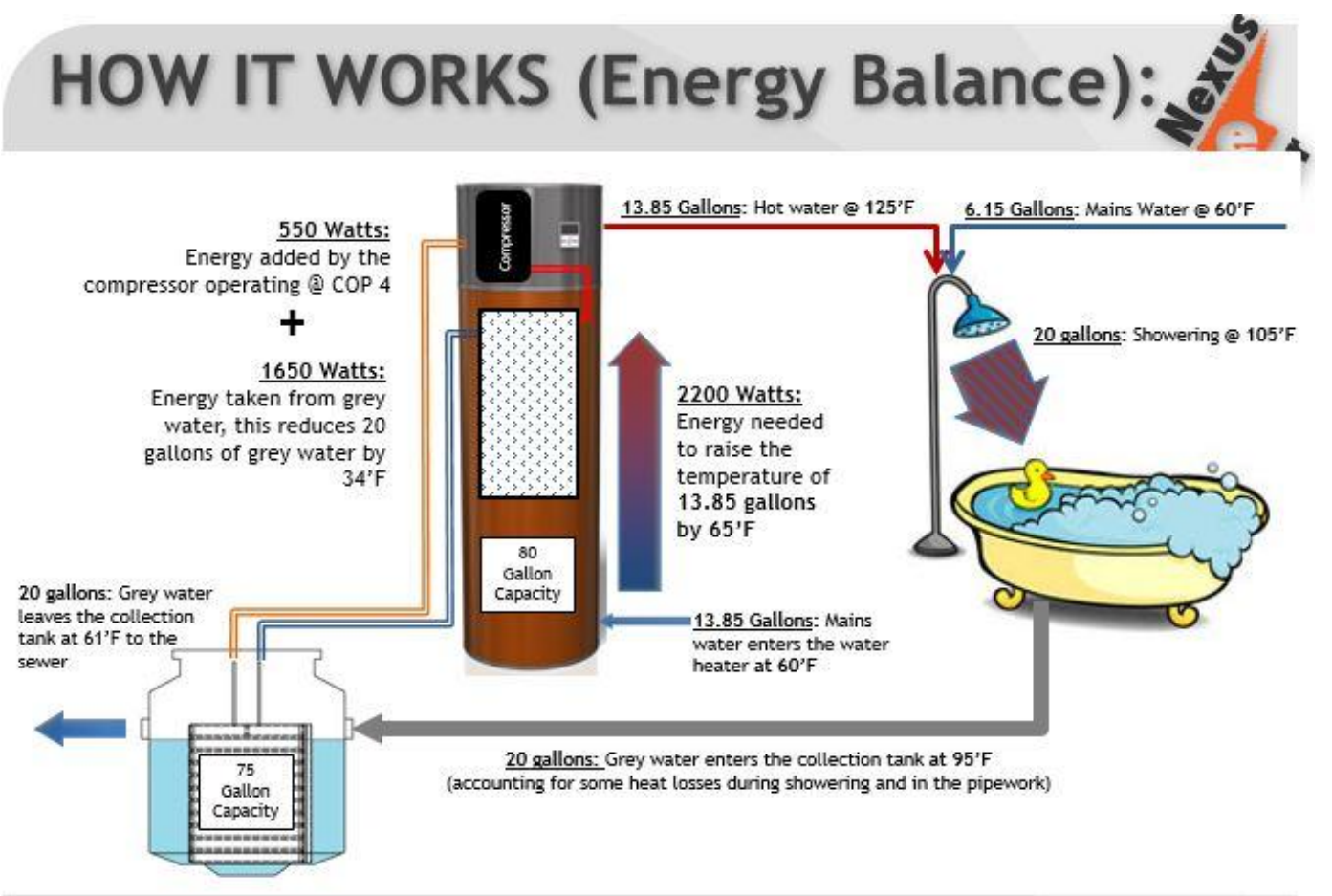

Fig. 5. Conceptual Schematic of the Nexus graywater heat recovery system, provided by Nexus eWater

\subsection{PV Array Sizing}

We sized our photovoltaic array (21 panels, each $1.54 \mathrm{~m}^{2}$ ) [52] to produce $175 \mathrm{kWh}$ over the duration of the U.S. DOE Solar Decathlon 2015 competition period (175 kWh is the maximum energy use permitted by the competition rules [1]). The procedure outlined by Duffie and Beckman (2006) was used to perform the photovoltaic calculations [53]. Ten years of direct solar radiation data for Davis, CA (from 2005-2014) was obtained from CIMIS [54]. The following equations were used to calculate the appropriate solar angles:

Declination Angle $=\delta=23.45 \sin \left(\frac{360(284+n)}{365}\right)$

$B=(n-1) * \frac{360}{365}$

Equation of Time $=E o T=229.2(0.000075+0.01868 \cos B-0.032077 \sin B-0.014615 \cos 2 B-0.04089 \sin 2 B)$

Solar Time $=$ Standard Time $+4\left(L_{s t}-L_{l o c}\right)+$ EoT

Hour Angle $=w=15($ Solar Time -12$)$

Zenith Angle $=\theta_{Z}=\cos ^{-1}(\cos \phi \cos \delta \cos w+\sin \phi \sin \delta)$

Solar Azimuth Angle $=\gamma_{s}=\operatorname{sign}(w) * a b s\left(\frac{\cos ^{-1}\left(\cos \theta_{z} \sin \phi-\sin \delta\right)}{\sin \theta_{z} \cos \phi}\right)$

The adjusted solar radiation, $\mathrm{G}_{\mathrm{bt}}$, depends on the pitch of the roof, $\beta$ :

$G_{b t}=\cos \theta_{z} \cos \beta+\frac{\sin \theta_{z} \sin \beta\left(\gamma_{s}-\gamma\right)}{\cos \theta_{z}} G_{b}$

Although the nominal panel efficiency $n_{m p_{r e f}}$ for the SunPower E20-327 panels is 20.4\%[52], this efficiency is only attained at the reference cell temperature, $T_{c_{r e f}}$, of $25^{\circ} \mathrm{C}$. Panel efficiency decreases with increasing cell temperature:

$n_{m p}=n_{m p_{r e f}}-\mu_{n m p}\left(T_{c}-T_{c, r e f}\right)$

The actual cell temperature, $T_{c}$, is a function of the wind speed, $V$, and $T_{a}$-both of which were obtained from CIMIS data for Davis averaged from 2005-2014 [54]:

$T_{c}=\frac{G_{T}}{800}\left(\frac{9.5}{5.7+3.8 V}\right)\left(T_{\text {NOCT }}-T_{a, \mathrm{NOCT}}\right)+T_{a}$ 
The electricity production of a panel was calculated as:

$E_{\text {panel }}=n_{m p} *$ derate $* A_{\text {panel }}$

The derate factor measures electricity that the inverter converts from DC to AC [55].

3. Results and Discussion

3.1. Aggie Sol Construction versus Conventional Construction

This model analyzes three facets of the team's construction effort, in-line framing, low window to wall ratio, and thermal mass, independently before accounting for the combined heating and cooling energy savings of all three. Fig. 6 illustrates the annual heating and cooling energy consumption associated with the different construction scenarios analyzed with BEopt. Fig. 7 depicts the annual heating and cooling loads associated with these construction scenarios.

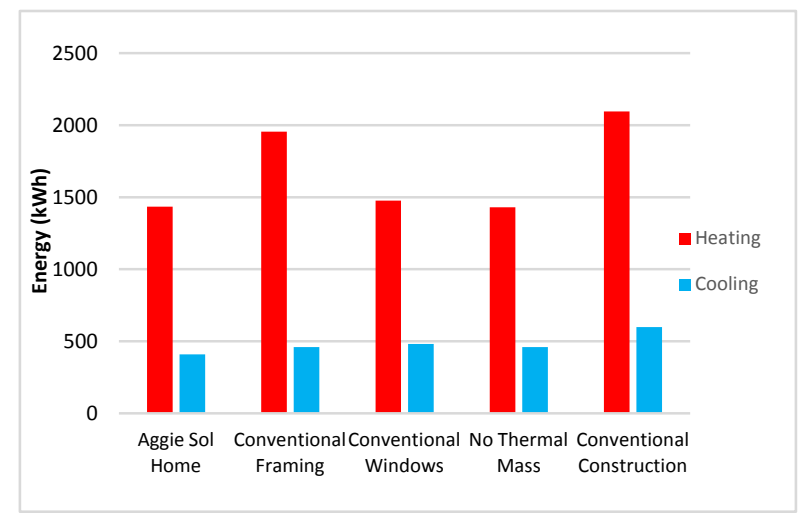

Fig. 6. Annual Heating and Cooling Energy

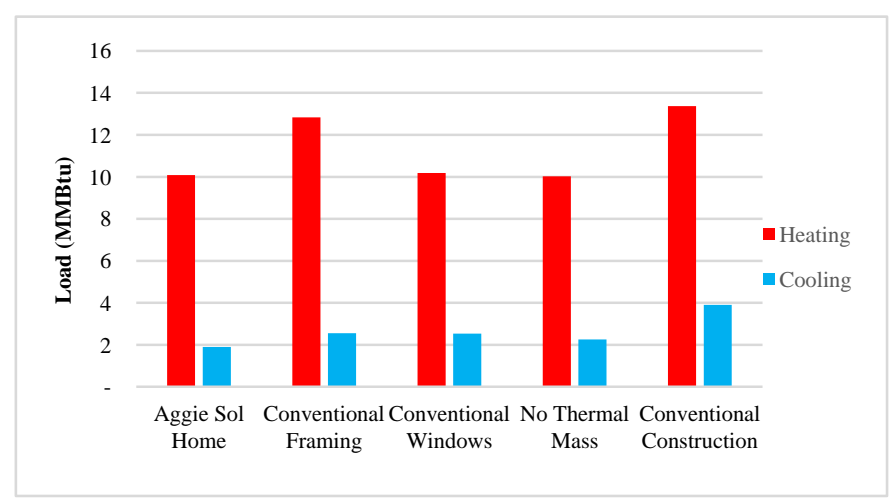

Fig. 7. Annual Heating and Cooling Loads 


\subsubsection{In-Line Framing versus Conventional Framing}

The combined effect of high insulation and in-line framing resulted in a tremendous reduction in heating and cooling loads throughout the year. According to BEopt, conventional framing of the home would result in an annual heating load of 12.83 million BTUs (13.54 GJ). By comparison, the in-line framing method produces an annual heating load of 10.09 million BTUs (10.65 GJ), a savings of 2.74 million BTUs (2.89 GJ) and a $21.4 \%$ reduction. Additionally, the "Aggie Sol framing" method produces an annual cooling load of 1.90 million BTUs (2.00 GJ) while conventional framing would generate an annual cooling load of 2.55 million BTUs (2.69 GJ) - a savings of 25.6\%. Since loads correlate with heating and cooling electricity consumption, savings were also forecasted for electricity. Conventional framing would require $1955 \mathrm{kWh}$ for heating and $459 \mathrm{kWh}$ for cooling. Aggie Sol framing, alternatively, would require only $1435 \mathrm{kWh}$ for heating, a reduction of $26.6 \%$, and 409 $\mathrm{kWh}$ for cooling, a decrease of $12.2 \%$.

\subsubsection{Aggie Sol Windows versus Conventional Windows}

The Aggie Sol windows decrease the annual cooling load and cooling energy consumption of the house. The cooling load falls from 2.54 million BTUs (2.68 MJ) to 1.90 million BTUs $(2.00 \mathrm{MJ})$, a $25.2 \%$ reduction. The cooling energy decreases from $482 \mathrm{kWh}$ to $409 \mathrm{kWh}$, a $17.7 \%$ reduction. The annual heating load only decreases by $0.9 \%$ and the heating energy is virtually identical $-1435 \mathrm{kWh}$ for the Aggie Sol windows versus $1476 \mathrm{kWh}$ for conventional windows. The low window to wall ratio and the low solar heat gain coefficient greatly reduces solar heat gain into the house, which reduces the comparative cooling demand in summer months but has a negligible impact on the comparative heating demand in winter months

\subsubsection{Thermal Mass versus No Thermal Mass}

The "No Thermal Mass" case produced an annual heating load of 10.03 million BTUs (10.58 MJ), which was $0.6 \%$ smaller than the annual heating load of the Aggie Sol Home. The "No Thermal Mass" case requires $1430 \mathrm{kWh}$ of heating energy, which is almost identical to the 1435 $\mathrm{kWh}$ required by the baseline case. Thus thermal mass in the floor neither reduces the heating load nor does it save heating energy. But the "No Thermal Mass" case did generate an annual cooling load of 2.25 million BTUs (2.37 MJ), which exceeds the annual cooling load of the Aggie Sol Home by $15.8 \%$. The corresponding cooling energy demand of the "No Thermal Mass" case and Aggie Sol Home was 409 kWh and 459 $\mathrm{kWh}$, respectively, a $12.2 \%$ difference.

By far the single most important construction method in improving the energy efficiency of the Aggie Sol home is in-line framing. The Aggie Sol home demands $1844 \mathrm{kWh}$ year-round for heating and cooling - conventional framing would increase this quantity to $2414 \mathrm{kWh}$, a $23.6 \%$ jump. But using conventional windows or neglecting to add thermal mass would only increase the baseline heating and cooling energy consumption to $1958 \mathrm{kWh}$ and $1889 \mathrm{kWh}$, respectively. Both of these efficiency improvements are less than $6 \%$.

\subsubsection{Aggie Sol Construction versus Conventional Construction}

The "Conventional construction" case modeled the Aggie Sol home with conventional framing, a 15\% window to wall ratio, a U-factor of 0.37 and an SHGC of 0.3, and no thermal mass in the floor. Conventional construction generated a yearly heating load of 13.37 million BTUs (14.11 MJ) and a yearly cooling load of 3.90 million BTUs (4.11 MJ). The Aggie Sol home reduces heating and cooling loads by $24.5 \%$ and $51.4 \%$, respectively. Conventional construction requires $2095 \mathrm{kWh}$ electricity for heating and $598 \mathrm{kWh}$ electricity for cooling annually. The overall heating and cooling energy demand of the Aggie Sol home is $2694 \mathrm{kWh}$, a $31.6 \%$ reduction in home energy use.

\subsection{Aggie Sol Appliances versus Conventional Appliances}

Not only did the annual energy consumption of the home appliances decrease substantially, but also the energy associated with hot water and space cooling also fell (Table 7). The appliances selected for the Aggie Sol home reduced energy consumption by $17.5 \%$ and hot water energy by $8.4 \%$. Waste heat from inefficient appliances contribute to internal heat gains, which are responsible for $20 \%$ of a home's summer cooling loads [3]. By utilizing energy efficient appliances, the Aggie Sol Home reduced the annual cooling energy use by $2.3 \%$. Since less waste heat was available from the appliances during the winter, the home required $1.1 \%$ more heating energy. Altogether, the appliances selected for the Aggie Sol home produced an annual energy savings of almost $400 \mathrm{kWh}$, corresponding to a $9.7 \%$ reduction over conventional appliances.

Table 7

\begin{tabular}{llll} 
Energy Usage Comparison of Aggie Sol Appliances versus Conventional Appliances. \\
\hline $\begin{array}{l}\text { Annual Energy Use } \\
\text { (kWh/year) }\end{array}$ & $\begin{array}{l}\text { Aggie Sol } \\
\text { Appliances }\end{array}$ & $\begin{array}{l}\text { Conventional } \\
\text { Appliances }\end{array}$ & $\begin{array}{l}\% \\
\text { Savings }\end{array}$ \\
\hline Appliances & 1617 & 1961 & $17.5 \%$ \\
Hot Water & 671 & 732 & $8.4 \%$ \\
Heating & 1435 & 1419 & $-1.1 \%$ \\
Cooling & 409 & 419 & $2.3 \%$ \\
Total & 4132 & 4531 & $9.7 \%$ \\
\hline
\end{tabular}

\subsection{Aggie Sol Heating and Cooling System Energy Savings}

\subsubsection{Energy Savings of the Night Sky Cooling System}

Since the night sky pump runs for several hours during summer nights, its power draw has an impact on the overall energy usage of the home. To minimize the power draw, the sprinklers operated at $10 \mathrm{psi}(0.69 \mathrm{bar})$, even though $20 \mathrm{psi}(1.38 \mathrm{bar})$ is the bottom end of the operating range listed by most manufacturers [35]. However, we determined experimentally that sprinkler coverage on the roof was still adequate and that the sprinklers would still produce the fine mist needed for radiative cooling to occur. By running an under-pressurized system, the team was able 
to use an Armstrong pump that drew $0.576 \mathrm{~kW}$ [34] instead of a Grundfos pump that drew 0.944 kW [36]. Annually, the Armstrong pump consumed $65.87 \mathrm{kWh}$ of electricity, while the Grundfos consumed $107.96 \mathrm{kWh}$, an energy savings of $42 \mathrm{kWh}$.

\subsubsection{Aggie Sol Heating and Cooling System versus Forced Air Distribution System}

Table 8 provides the heating and cooling energy used year-round by both systems. The Aggie Sol heating and cooling system is $83.3 \%$ more energy efficient in cooling mode and $83.8 \%$ more energy efficient in heating mode than the default forced air distribution system in BEopt. During cooling mode, this tremendous improvement in energy efficiency occurs because two weak circulating pumps are the only sources of energy usage. By contrast, the default forced air distribution system requires an air handler and a reversible heat pump, both of which draw much more energy than recirculating water pumps. During heating mode, the State HPWH replaces the night sky pump as the second source of energy usage (the radiant pump distributes water in both modes). Nevertheless, there is a large gain in energy efficiency compared to a forced air distribution system because no duct losses occur, a HPWH has replaced a gas furnace, and the air handler has still been eliminated.

Table 8

Heating and Cooling Energy (kWh/yr) for Aggie Sol and Forced Air Systems

\begin{tabular}{llll}
\hline System & Heating Energy & Cooling Energy & Total Energy \\
\hline Radiant/Night Sky & 1435 & 409 & 1844 \\
Forced Air & 2636 & 750 & 3387 \\
\hline
\end{tabular}

\subsection{Nexus Graywater Heat Recovery System versus Conventional Domestic Hot Water System}

The Nexus e-Water Calculator [56] was used to determine the energy savings of the Nexus graywater heat recovery system. This program calculated the electricity consumed by the NEXheater and other water heaters. The program required the following inputs: zipcode, household size, and fixture efficiency. The Aggie Sol water fixtures were assumed to be "highly efficient," since water efficiency was one of the cornerstones of the appliance scoring methodology. The program calculated $2.689 \mathrm{kWh} /$ day of electricity consumption by the NEXheater. By extrapolating the daily electricity consumption of the NEXheater and alternative water heaters, we obtained the yearly values listed in Table 9. Note that the NEXheater has a coefficient of performance of 4.0, which exceeds the highest EF of any HPWH certified by Energy Star at the time of this analysis - the GE Geospring GEH50DEEJSC water heater has an EF of 3.39 [20].

Table 9

NEXheater Performance versus Alternative Water Heaters

\begin{tabular}{lccc}
\hline Water Heater Type & $\begin{array}{l}\text { Daily Energy Demand } \\
\text { (kWh/day) }\end{array}$ & $\begin{array}{l}\text { Annual Energy Demand } \\
\text { (kWh/year) }\end{array}$ & $\begin{array}{l}\% \\
\text { Difference }\end{array}$ \\
\hline NEXheater & 2.69 & 981 & \\
Heat Pump, EF 3.39 & 3.17 & 1158 & $18.1 \%$ \\
Electric Resistance & 11.95 & 4362 & $344.4 \%$ \\
Gas Tank & 18.54 & 6768 & $589.6 \%$ \\
Gas Tankless & 13.12 & 4787 & $387.8 \%$ \\
Condensing Gas Tankless & 11.20 & 4089 & $316.6 \%$ \\
\hline
\end{tabular}

Natural gas tank energy consumption is typically measured in therms, but to make an equivalent comparison, therms have been converted to $\mathrm{kWh}$ (using the relationship 1 therm equals $29.3 \mathrm{kWh}$ ). The NEXheater consumes $981 \mathrm{kWh}$ of electricity annually while its closest competitor, the GE Geospring GEH50DEEJSC, consumes $1158 \mathrm{kWh}$ annually, which is an additional $177 \mathrm{kWh}$. All of the other water heater alternatives consume over triple the amount of energy as the NEXheater.

\subsection{Photovoltaic Electricity Production}

Davis has mostly sunny days and high insolation throughout the year, which makes the location great for solar energy production. Fig. 8 illustrates the typical annual insolation in Davis. The data was obtained from CIMIS, which utilizes pyranometers in a horizontal position at a height of $2.0 \mathrm{~m}$ above ground to measure total incoming solar radiation. [54] 


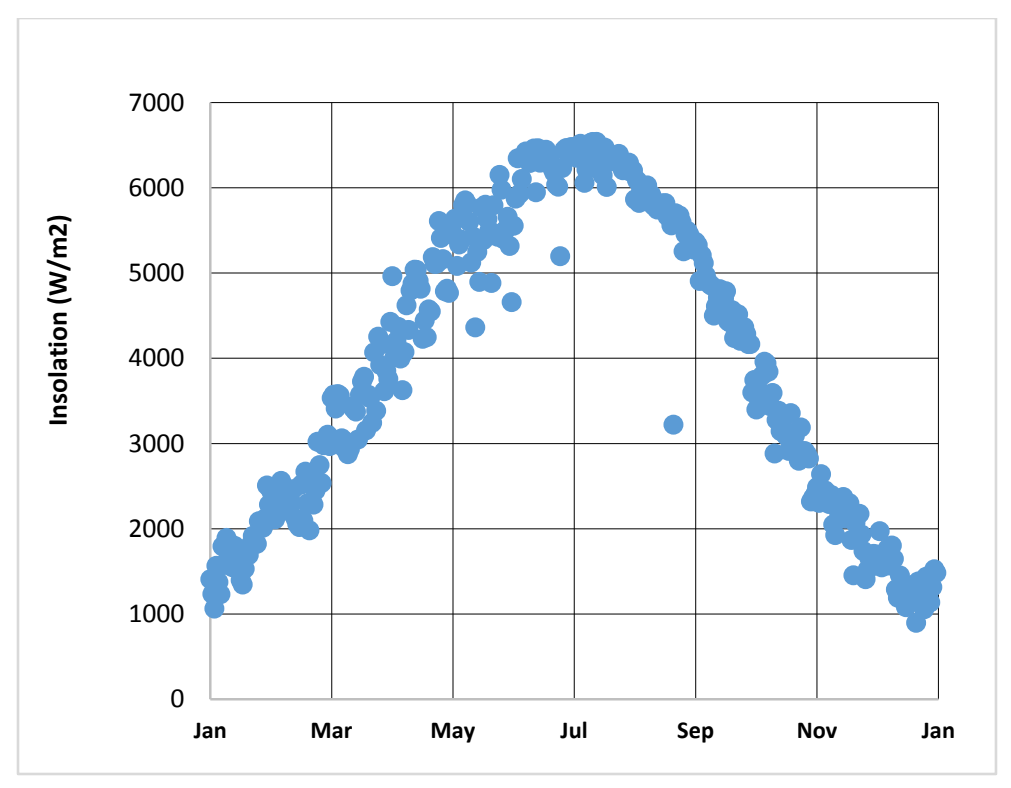

Fig. 8. Average Insolation $\left(\mathrm{W} / \mathrm{m}^{2}\right)$ in Davis, CA throughout the year

The night sky sprinklers not only cool the home but also clean dust off the panels. Dust accumulation can cause a $40 \%$ reduction in panel efficiency, and by extension photovoltaic electricity production, throughout the year [10]. A reduction of this magnitude in the Aggie Sol home would result in the house going from slightly producing net-positive energy onto the grid to drawing $30 \%$ of its energy from the grid.

\subsection{Annual Energy Consumption and Overall Energy Efficiency}

Over the course of a year, the Aggie Sol home consumes $5854 \mathrm{kWh}$ of electricity, whereas a conventional home of similar size would consume $8472 \mathrm{kWh}$, a $43.8 \%$ difference (Fig. 9). Since the Aggie Sol home produces $6611 \mathrm{kWh}$ of electricity from photovoltaics, it is $12.9 \%$ energy net-positive. By far the single most important construction method in improving the energy efficiency of the Aggie Sol home is in-line framing. The Aggie Sol home requires $1844 \mathrm{kWh}$ annually for heating and cooling — conventional framing would require $2414 \mathrm{kWh}$, a $23.6 \%$ increase. The other construction techniques - adding thermal mass and reducing the window to wall ratio—only caused small improvements in energy efficiency.

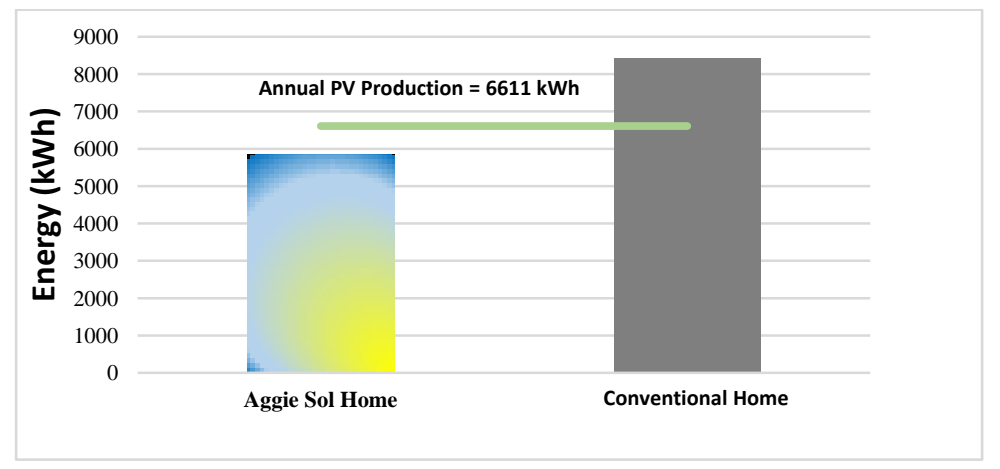

Fig. 9. Annual Energy Consumption of Aggie Sol Home versus Conventional Home

Appliances are the top energy user in the Aggie sol home, followed by the heating and cooling system and hot water production. Fig. 10 indicates that appliances, heating and cooling, and hot water production combine for $74 \%$ of the annual electricity bill. As a result, we focused on limiting heating and cooling loads, optimizing the heating and cooling system, choosing efficient appliances, and incorporating the Nexus graywater heat recovery system - doing so presented the best returns on our energy efficiency investment. 


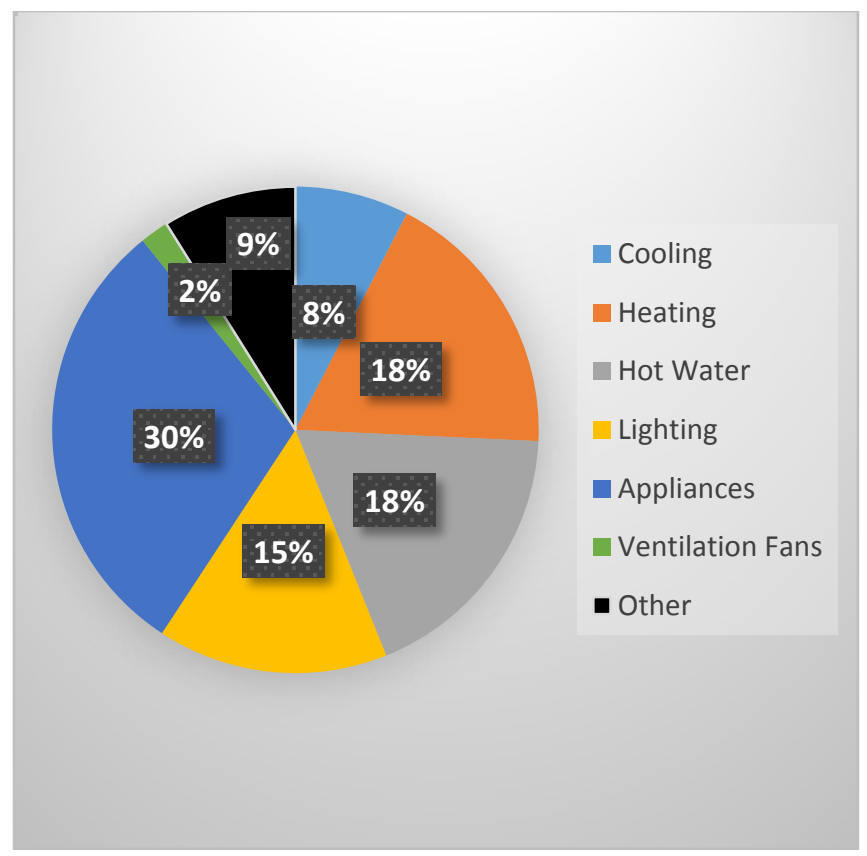

Fig. 10. Aggie Sol Home Energy Usage Breakdown by Category

\section{Conclusions} home:

The combined BEopt-Microsoft Excel® energy model yielded intriguing results about the different energy efficient features of the Aggie Sol

(1) The Aggie Sol construction method substantially reduced annual heating and cooling energy - the single most effective technique was in-line framing, which decreased space conditioning electricity usage by $23.6 \%$. The low window to wall ratio and the use of gypsum concrete as thermal mass only produced $5.8 \%$ and $2.4 \%$ in annual energy savings.

(2) The appliance selection saved electricity by lessening the quantity of water to be heated, reducing actual appliance energy usage, and eliminating waste heat that would otherwise contribute to internal gains. Our appliance selection saved nearly $400 \mathrm{kWh}$ compared to the benchmark appliances in BEopt, a $9.7 \%$ reduction.

(3) The NEXheater, with an EF of 4.0, expended $177 \mathrm{kWh}$ less energy annually than the GE Geospring 50 gallon HPWH with EF 3.39. Thus, graywater heat recovery is an even more efficient method of domestic hot water production than the most efficient HPWH available on the market.

(4) The Aggie sol heating and cooling system reduces energy consumption by eliminating an air handler and ductwork, using two lowenergy recirculating water pumps (radiant pump and night sky pump) in cooling mode. In heating mode, instead of a gas furnace, the home employs a highly efficient HPWH. Annually, compared to a forced air distribution system, our system is $83.3 \%$ more energy efficient in cooling mode, and $83.8 \%$ more energy efficient in heating mode.

(5) The Aggie Sol home is a positive-net energy house during year-round operation in Davis, CA. The home produces $6611 \mathrm{kWh}$ while consuming only $5854 \mathrm{kWh}$-it is $12.9 \%$ positive-net energy. By contrast, a conventionally built house would require $8472 \mathrm{kWh}$ electricity annually. Assuming the same photovoltaic array, a conventional house would obtain $21.9 \%$ of its energy from the grid. The Aggie Sol home is $43.8 \%$ more energy efficient than a conventional home, with the same floor plan, exposed to the Davis, CA, climate.

\section{Acknowledgements}

We are extremely grateful to all of the students, faculty, staff, and mentors who spent time and energy designing and constructing the Aggie Sol Home. We would like to thank UC Davis for all of its financial and infrastructural support. We also would like to express gratitude to all of the organizations that donated their valuable time, money, and resources to supporting our project:

\begin{tabular}{l}
\hline Organization Name \\
\hline Amramp \\
Armstrong \\
AUS Decking, Inc. \\
AutoDesk \\
Bluebeam \\
Bosch \\
Brown Construction \\
Building Materials and Construction Services \\
Center for Information Technology Research in the Interest of Society \\
Daikin \\
Davis Energy Group
\end{tabular}


Fastenal

Gudgel Yancey Roofing Inc.

Heising-Simons Foundation

Honda

Integrated Comfort

JamesHardie

Nexus eWater

Pacific Gas and Electric

Simpson Strong-Tie

SnapNrack PV Mounting Systems

Sunbelt Rentals

SunPower

Tandem Properties

UC Davis Office of the Provost and Executive Vice Chancellor

UC Davis College of Agricultural and Environmental Sciences

UC Davis College of Engineering

UC Davis Division of Humanities, Arts, and Cultural Studies

UC Davis Division of Social Sciences

UC Davis Energy Efficiency Center

UC Davis Energy Institute

UC Davis Office of Graduate Studies

UC Davis Student Affairs

UC Davis Undergraduate Education

UC Davis Utilities

U.S. Department of Energy

Viega

Visions Paint Recycling

Weyerhaeuser

We owe a special debt to the Davis Energy Group, especially senior engineer Alea German, for mentoring our energy modeling team for the past year. We would like to give another special thank you to Nexus eWater for not only donating their system but also explaining how to properly model its energy usage. And certainly the brilliance of the combined radiant/night sky cooling system would not have been possible without the tremendous mentorship and installation assistance of long-time energy consultant Richard Bourne.

\section{References}

1. $\quad$ U.S. Department of Energy Solar Decathlon Rules. 2014: U.S. Department of Energy.

2. Premier Hybrid 50-80 Gallon Electric Heat Pump Water Heater. 2015, Ashland City, TN: State Water Heaters.

3. Krigger, J., Residential energy: cost savings and comfort for existing buildings. 2009: Saturn Resource Management, Inc.

4. Richmond, C. and B. Hitchner, The NEXheater ONE. Nexus eWater.

5. 2013 California Plumbing Code, C.B.S. Commission, Editor. 2013: Sacramento, CA.

6. Hermann, A., The Nexus Hub. 2013, Australia: Nexus eWater.

7. Nexheater Introduction. 2015, Nexus eWater.

8. SunPower SPR-5000m/SPR-6000m/SPR-7000m/SPR-8000m Installation Guide. 2010, San Jose, CA: SunPower Corporation.

9. $\quad$ Philibert, C., Technology roadmap: solar photovoltaic energy. 2014: OECD/IEA.

10. Sulaiman, S.A., et al., Effects of dust on the performance of PV panels. World Academy of Science, Engineering and Technology, 2011. 58: p. 588-593.

11. BEopt. 2015, National Renewal Energy Laboratory: Golden, CO.

12. Wilson, E., et al., 2014 Building America House Simulation Protocols. 2014: National Renewable Energy Laboratory.

13. Sprague, P.E., The origin of balloon framing. The Journal of the Society of Architectural Historians, 1981: p. 311-319.

14. $\quad$ Knauf Data Sheet BI-BT-DS 09-14. 2014, United States: Knauf Insulation.

15. 072116 Blanket Insulation (Eco-Batt). 2015, Shelbyville, IN: Knauf Insulation GmbH.

16. Persson, M.-L., A. Roos, and M. Wall, Influence of window size on the energy balance of low energy houses. Energy and Buildings, 2006. 38(3): p. 181-188.

17. Bradshaw, T., \#JABSO0235 Solar Decathlon. 2015, Jeld-Wen: Klamath Falls, OR.

18. Athienitis, A. and Y. Chen, The effect of solar radiation on dynamic thermal performance of floor heating systems. Solar Energy, 2000. 69(3): p. 229-237.

19. ICF Homes \& Thermal Mass. 2014, NREL.

20. EnergyStar. 2015, U.S. EPA.

21. Certified Residential Dishwashers. 2014, U.S. EPA EnergyStar.

22. Installation Instructions 30" Electric Slide-In Range. United States: Frigidaire.

23. SGE63E05UC28 Instructions for Use. Bosch Home Appliances: Huntington Beach, CA.

24. SGE63E06UC Evolution 24 Special Application Dishwasher Fr. Bosch: Huntington Beach, CA.

25. Front Load Washer FFFW5000QW. 2014, Charlotte, NC: Electrolux Home Products.

26. Front Load Dryer FFQE5000QW. 2014, Charlotte, NC: Electrolux Home Products.

27. UN46H5203AF. 2015: Samsung Electronics America.

28. Top Mount Refrigerators FFHT1831QS 2014, Charlotte, NC: Electrolux Home Products, Inc. .

29. All about the Installation of your Washer. Frigidaire. 
30. H5005-SpecSheet 7-29-14-1. 2014, Samsung Electronic Arts.

31. RPLS730B / RPLS731B 7-Day Programmable Timer for Lights and Motors. 2011, Golden Valley, MN: Honeywell International Inc. . 32. Zone Sentry Ball Valve Zone Valve 2011, Cranston, RI: Taco Inc.

33. ETC Single Stage Electronic Temperature Control Delphos, Ohio: Ranco.

34. Install Guide CT80. China: Radio Thermostat.

35. E.2 Series Circulators: E 12.2/E12.2B Submittal 2012, Buffalo, NY: Armstrong Integrated.

36. ProRadiant Heating and Cooling Design Manual. 2015, Wichita, KS: Viega LLC.

37. Standard, A., Standard 55-2010. Thermal environmental conditions for human occupancy, 2010.

38. Radiant Cooling Design Manual. First ed. 2013, Apple Valley, MN: Uponor.

39. Complete Design Assistance Manual (CDAM). Seventh ed. 2011, Apple Valley, MN: Uponor.

40. Andrews, J., Better duct systems for home heating and cooling. 2001, Brookhaven National Laboratory (US).

41. Incropera, F.P. and D. Dewitt, P, Introduction to Heat Transfer. 2002, John Wiley \& Sons.

42. Ralph, H., et al., General chemistry: Principles and modern applications. Prentice Hall, 2007: p. 606.

43. Model 0013 Cartridge Circulator. 2008, Cranston, RI: Taco Inc.

44. Part, C., 430. Energy conservation program for consumer products, 1998.

45. Larson, B. and K. Nicholas, Laboratory Assessment of GE GEH50DFEJSRA Heat Pump Water Heater. 2015, Northwest Energy Efficiency Alliance: Seattle.

46. Phone Interview with Technical Representative, P. Alemi, Editor. 2015, State Water Heaters.

47. Bourne, R., Night Sky Cooling. 2015.

48. Clark, D., et al., Determination of the Clear Sky Emissivity For Use in Cool Storage Roof and Roof Pond Applications, P.S.R. Group, Editor., University of Nebraska at Omaha: Omaha, NE.

Berdahl, P. and R. Fromberg, The thermal radiance of clear skies. Solar Energy, 1982. 29(4): p. 299-314.

Berdahl, P. and M. Martin, Emissivity of clear skies. Solar Energy, 1984. 32(5): p. 663-664.

Chen, B., et al. Measurement of night sky emissivity in determining radiant cooling from cool storage roofs and roof ponds. in Proceedings of the National Passive Solar Conference. 1995. Citeseer.

Duffie, J.A. and W.A. Beckman, Solar Engineering of Thermal Processes. 2006, JOHN WILEY \& SONS, INC. NY.

California Irrigation Management Information System. 2015, California Department of Water Resources: CA.

Dobos, A.P., PVWatts version 5 manual. National Renewable Energy Laboratory, September, 2014.

Nexus eWater Calculator 20150509. 2015, Nexus eWater. 